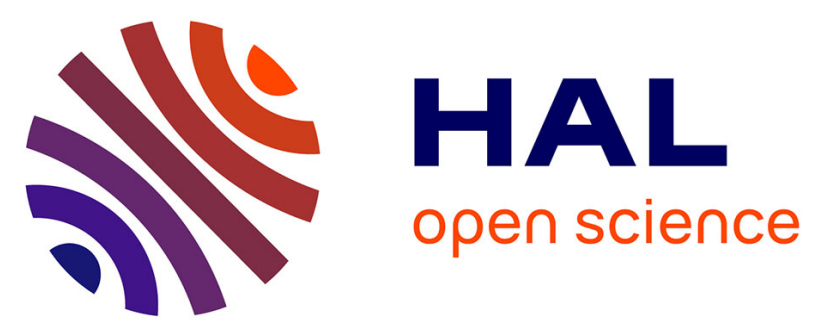

\title{
Hydroxyapatite supported bimetallic cobalt and nickel catalysts for syngas production from dry reforming of methane
}

\author{
Thanh Son Phan, Abdoul Razac Sane, Bruna Rêgo de Vasconcelos, Ange \\ Nzihou, Patrick Sharrock, Didier Grouset, Doan Pham Minh
}

\section{To cite this version:}

Thanh Son Phan, Abdoul Razac Sane, Bruna Rêgo de Vasconcelos, Ange Nzihou, Patrick Sharrock, et al.. Hydroxyapatite supported bimetallic cobalt and nickel catalysts for syngas production from dry reforming of methane. Applied Catalysis B: Environmental, 2018, 224, p.310-321. 10.1016/j.apcatb.2017.10.063 . hal-01630309

\section{HAL Id: hal-01630309 https://hal.science/hal-01630309}

Submitted on 20 Oct 2018

HAL is a multi-disciplinary open access archive for the deposit and dissemination of scientific research documents, whether they are published or not. The documents may come from teaching and research institutions in France or abroad, or from public or private research centers.
L'archive ouverte pluridisciplinaire HAL, est destinée au dépôt et à la diffusion de documents scientifiques de niveau recherche, publiés ou non, émanant des établissements d'enseignement et de recherche français ou étrangers, des laboratoires publics ou privés. 


\title{
Hydroxyapatite supported bimetallic cobalt and nickel catalysts for syngas production from dry reforming of methane
}

\author{
Thanh Son Phan, Abdoul Razac Sane, Bruna Rêgo de Vasconcelos, Ange Nzihou, Patrick Sharrock, \\ Didier Grouset, Doan Pham Minh*
}

Université de Toulouse, Mines Albi, UMR CNRS 5302, Centre RAPSODEE, Campus Jarlard, F-81013 Albi cedex 09, France

\begin{abstract}
A B S T R A C T
Hydroxyapatite (HAP, $\mathrm{Ca}_{10}\left(\mathrm{PO}_{4}\right)_{6}(\mathrm{OH})_{2}$ ) has all the criteria of a catalyst support, in particular its high thermal stability. However it is still less studied in the heterogeneous catalysis. For the first time, hydroxyapatite supported bimetallic Co-Ni catalysts were prepared and evaluated in the dry reforming of methane (DRM) process. Nanoparticles containing both nickel and cobalt were well formed on the surface of HAP by conventional impregnation methods. No modification of HAP structure was observed after metals deposition. DRM reaction was carried out at $700-750{ }^{\circ} \mathrm{C}$ and around 1.6 bar, using a fixed-bed reactor which was fed with a mixture of $20 \%$ vol $\mathrm{CH}_{4}, 20 \%$ vol $\mathrm{CO}_{2}$ and $60 \%$ vol $\mathrm{N}_{2} . \mathrm{CH}_{4}$ and $\mathrm{CO}_{2}$ conversion reached up to 60 and $68 \%$ at $700{ }^{\circ} \mathrm{C}$, respectively, and 73 and $79 \%$ at $750{ }^{\circ} \mathrm{C}$, respectively during long reaction times of 50-160 h. Water as a by-product could be quantified along the catalytic reaction indicating the implication of reverse water-gas-shift reaction. TEM-EDX analysis of the used catalysts recovered after catalytic tests showed that coke deposition was limited and there was slight modification of metals particle size. The results obtained were very promising for the design of an efficient catalytic system for DRM process.
\end{abstract}

Keywords:

Hydroxyapatite

Cobalt

Nickel

Bimetallic catalyst

Dry reforming of methane

\section{Introduction}

Waste management is up-to-date dominated by incineration and landfill technique. However, most of incinerators and landfill sites are not equipped with an energy or matter recovery system. In order to better valorize waste and biomass to energy, fuels and other added value and specialty products, new concepts are developed during these last decades including thermo-conversion route and biological route (Supporting information 1). Pyrolysis/gasification of biomass and waste is intensively studied during these last decades [1-4]. The highest challenge of this valorization route is the syngas cleaning. This last one is required to remove fine particles, condensable molecules and various gaseous pollutants $\left(\mathrm{H}_{2} \mathrm{~S}, \mathrm{COS}, \mathrm{HCl}, \mathrm{NH}_{3} \ldots\right)$, which depend on the nature of feedstock, gasifier, and downstream utilization [5]. Much effort is still needed to make this route competitive and viable.

Methanisation is a biological process for the degradation of waste and biomass. Biogas is the main gaseous product which mainly contains $\mathrm{CH}_{4}$ and $\mathrm{CO}_{2}$. This appears as a good solution for the management of non-hazardous wastes with minimization of the initial investment cost compared to thermal routes (incineration or pyro-gasification). Biogas can be upgraded to produce biomethane or transformed into syngas by reforming processes [6-8].
Biogas reforming includes various processes such as steam reforming, dry reforming, partial oxidation, and auto-thermal oxidation. They generally need a solid catalyst. In fact, because of the chemical stability of $\mathrm{CO}_{2}$ and $\mathrm{CH}_{4}$, biogas reforming needs high temperature (usually $>700^{\circ} \mathrm{C}$ ). Thus, side reactions such as Boudouard reaction and methane cracking take place leading to coke deposition. Steam reforming is found to be efficient for the conversion of biogas into syngas, with low catalytic deactivation rate. The presence of vapor allows gasifying coke deposition and so limiting catalytic deactivation. However, steam reforming is an energy-intensive process because of its high operational temperature and high water to hydrocarbon ratios used (3-4 for industrial installations). Partial oxidation and autothermal oxidation do not allow including carbon dioxide to the process. By these reasons, dry reforming of methane (DRM) has been intensively investigated these last years as new promising solution for biogas reforming. Generally, DRM is studied with an equimolar ratio mixture of $\mathrm{CH}_{4}$ and $\mathrm{CO}_{2}$ (Eq. (1)). Thermodynamic analysis of this reaction showed that it is favored at high temperature (i.e. above $700{ }^{\circ} \mathrm{C}$ ) and low pressure (i.e. around atmospheric pressure) $[9,10]$. The main products of this reaction are $\mathrm{CO}$ and $\mathrm{H}_{2}$, but coke deposition is inevitable below $900{ }^{\circ} \mathrm{C}$ at atmospheric pressure [10]. Water was usually reported as another by-product in the literature, and was recently quantified by

* Corresponding author

E-mail addresses: doan.phamminh@mines-albi.fr, doanhoa2000@yahoo.fr (D. Pham Minh). 
Rêgo de Vasconcelos et al. [11].

$\mathrm{CH}_{4}+\mathrm{CO}_{2} \rightarrow 2 \mathrm{CO}+2 \mathrm{H}_{2}$

The main challenge of DRM is related to the catalytic deactivation, together with side reactions such as reserve water-gas-shift reaction (RWGS). The deactivation is mostly due to coke deposition and catalyst modification (active phase and/or support) at high temperature [12-15]. Thus, much work was devoted to the development of new performing catalysts to prevent catalytic deactivation. The minimization of the size of nickel particles as active phase was frequently attempted [13]. In fact, coke formation can be inhibited by using highlydispersed nickel particles [16-18]. Catalyst support plays also important role. Supports having high basicity and strong metal-support interaction are researched $[19,20]$. High basicity favors $\mathrm{CO}_{2}$ adsorption and limits coke formation while strong metal-support interaction limits metal particles sintering [21-23].

Conventional catalytic supports including $\mathrm{Al}_{2} \mathrm{O}_{3}, \mathrm{MgO}, \mathrm{TiO}_{2}, \mathrm{ZrO}_{2}$, $\mathrm{SiC}$, zeolites, and nanostructured carbons were frequently reported in the literature for DRM [24-28]. The combination of several metal oxides allowed improving catalytic performance $[27,29,30]$. However, up-to-date and to the best of our knowledge, there is not application of DRM at large industrial scale yet. A highly-performing catalytic system is still to be developed and it is important to enlarge research area on other types of catalyst. For this reason, our current research is focused on synthetic calcium hydroxyapatite $\left(\mathrm{Ca}_{10}\left(\mathrm{PO}_{4}\right)_{6}(\mathrm{OH})_{2}\right.$, HAP)-based catalysts.

HAP has all the criteria required for a catalytic support: high specific surface area, with or without mesopores depending on the synthesis conditions, very low water solubility, and high thermal stability [11,13,31-33]. In addition, it contains both acid and basic sites and the density of these sites can be controlled by varying the molar ratio of $\mathrm{Ca}$ to P. At high temperature, partial dehydration can take place but this phenomenon is reversible under the presence of water vapor $[34,35]$. Thus HAP becomes less sensitive to the presence of water, which is usually formed during DRM process. All these properties make HAP as new potential support for heterogeneous catalytic processes. Boukha et al. [36] studied DRM over nickel loaded HAP in the temperature range of $600-800^{\circ} \mathrm{C}$. Encouraging results were obtained with high initial conversion of methane and carbon dioxide during $4 \mathrm{~h}$ of time-onstream. However, the catalytic stability was not investigated by these authors. Recently, we reported our last results on the catalytic performance of ruthenium and platinum supported HAP in DRM process. At low Pt loading of $0.73 \mathrm{wt} . \%$, the catalyst Pt/HAP prepared by the simple incipient wetness impregnation (IWI) showed interesting catalytic activity and stability during $50 \mathrm{~h}$ of time-on-stream (at $700{ }^{\circ} \mathrm{C}$ and atmospheric pressure) [11].

Although noble metals catalysts are known to have good catalytic performance, their high cost hinders their use at large scale. So, many researchers have focused on the use of transition metals such as nickel, cobalt, iron etc. as active phases. Despite showing high activity, these catalysts suffer from rapid deactivation mostly due to carbon deposition and metal sintering. In order to improve their stability, several approaches have been proposed such as the modification of methods for catalyst preparation or the addition of promoters. One of the most investigated approaches is the use of a second metal to enhance catalyst stability in DRM process. Takanabe et al. [37] showed that combining $\mathrm{Ni}$ and Co could enhance the catalyst activity and also suppress the carbon deposition during DRM. Zhang et al. [38] arrived at similar conclusions. They demonstrated that combining $\mathrm{Ni}$ and $\mathrm{Co}$ increased metal dispersion and generated stronger metal-support interaction when compared to the $\mathrm{Ni}$ and Co monometallic catalysts. Recent work of Wang et al. [39] highlighted again the beneficial effect of bimetallic Ni-Co catalysts compared to monometallic Ni or Co catalysts in DRM reaction.

This work investigated the catalytic performance of HAP supported nickel-cobalt bimetallic catalysts in DRM process. Nickel and cobalt were chosen for their high activity and their relative low cost compared to other metals while HAP appears as a new promising catalytic support as mentioned above.

\section{Materials and methods}

\subsection{Catalyst preparation}

Commercial HAP support $\left(60 \mathrm{~m}^{2} / \mathrm{g}\right.$, fine powder $)$ provided by PRAYON S.A. (Belgium) was used as catalytic support without further modification. Nickel nitrate $\left(\mathrm{Ni}\left(\mathrm{NO}_{3}\right)_{2} \cdot 6 \mathrm{H}_{2} \mathrm{O}\right.$, Fisher Scientific, $>98 \mathrm{wt}$ $\%)$ and cobalt nitrate $\left(\mathrm{Co}\left(\mathrm{NO}_{3}\right)_{2} \cdot 6 \mathrm{H}_{2} \mathrm{O}\right.$, Acros Organics, > $\left.98 \mathrm{wt} \%\right)$. Distilled water was also used for catalyst preparation.

Hydroxyapatite supported bimetallic nickel and cobalt catalysts were prepared by successive incipient wetness impregnation (SIWI) or incipient wetness co-impregnation (COI). For the catalysts prepared by SIWI method, HAP support was firstly impregnated with an aqueous solution of the first active metal. The volume of the solution and the concentration of this metal were calculated to reach the desired metal content in the final catalyst. After drying at $105^{\circ} \mathrm{C}$, the solid was calcined at $500{ }^{\circ} \mathrm{C}$ under air atmosphere. This procedure was repeated for the deposition of the second active metal. For the catalysts prepared by COI method, HAP support was impregnated with an aqueous solution of both active metals precursors. Table 1 summaries the catalysts prepared. The theoretical metals content was $2.85 \mathrm{wt} . \%$ for each metal in each catalyst.

\subsection{Catalyst characterization}

Elemental analysis was carried out using inductive coupled plasma atomic emission spectroscopy (ICP-AES) with a HORIBA Jobin Yvon Ultima 2 apparatus. Prior to the analysis, solid catalysts were dissolved in a strong acid mixture of $\mathrm{HNO}_{3}$ and $\mathrm{HCl}$. X-ray diffraction (XRD) data were collected using a Phillips Panalytical X'pert Pro MPD diffractometer with a Cu $\mathrm{K}_{\alpha}(1.543 \AA$ ) radiation source and a nickel filter to suppress the $C u_{K \beta}$ ray. The specific surface area was measured by nitrogen adsorption following standard vacuum drying at $105{ }^{\circ} \mathrm{C}$, using the BET method (MICROMETRICS Gemini Vacprep 061). Scanning electron microscopy coupled with energy dispersive spectroscopy (SEM-EDX) measurement was performed on a Philips XL30 ESEM apparatus (FEI Company). Transmission electron microscopy coupled with energy dispersive spectroscopy (TEM-EDX) was done with a FEG JEOL JEM $2100 \mathrm{~F}$ equipped with a HAADF detector. XRD, SEM and TEM analyses were done with fresh catalyst after calcination at $500{ }^{\circ} \mathrm{C}$ or with spent catalysts recovered after catalytic tests. From TEM image, metals particle size was evaluated with up to 300 particles.

\subsection{Catalytic evaluation}

Catalytic test was carried out with a tubular fixed-bed ceramic reactor (internal diameter of $8 \mathrm{~mm}$, length of $25 \mathrm{~cm}$ ), which was surrounded by an Inconel625 tube to protect against mechanical impacts. The details are described elsewhere [11]. Briefly, the catalytic bed was set at the center of the reactor and was fixed by fine powder of inert support ( $\alpha$-alumina). The reaction temperature was controlled by a

Table 1

Catalysts prepared in this work.

\begin{tabular}{lll}
\hline Catalyst & Preparation method & Preparation procedure \\
\hline Co-Ni/HAP_SIWI & SIWI & $\begin{array}{l}\text { Cobalt deposition, followed by nickel } \\
\text { deposition } \\
\text { Nickel deposition, followed by cobalt } \\
\text { deposition } \\
\text { Ni-Co/HAP_SIWI }\end{array}$ SIWI \\
Ni-Co/HAP_COI & COI &
\end{tabular}


thermocouple set at the center of the catalyst bed. The reactor was heated by an electrical furnace. The reaction pressure was observed around 1.6 bar which was slightly higher than the atmospheric pressure. This was due to the pressure drop inside the reactor tube provoked by fine powders of inert support and catalyst. For a given catalytic test, $340 \mathrm{mg}$ of catalyst, diluted two times with $\mathrm{SiC}$, both under fine powder form, were used. Prior to the test, the catalyst was heated under $\mathrm{N}_{2}$ atmosphere $(70 \mathrm{NmL} / \mathrm{min})$ to $700{ }^{\circ} \mathrm{C}$ and reduced in-situ at this temperature by $4 \mathrm{vol} . \% \mathrm{H}_{2} / \mathrm{N}_{2}$ stream $(70 \mathrm{NmL} / \mathrm{min})$ for $2 \mathrm{~h}$. Then, the reactor system was set at the working temperature under $\mathrm{N}_{2}$ atmosphere. At the working temperature, the reactor was fed with a gas mixture of $\mathrm{CH}_{4}\left(20\right.$ vol.\%) and $\mathrm{CO}_{2}\left(20\right.$ vol.\%) diluted in $\mathrm{N}_{2}$ (total gas flow rate of $90 \mathrm{Nml} / \mathrm{min}$ ). This high dilution was applied due to security measures required in our laboratory, despite being far from the real biogas mixtures. The inlet gas composition and flow rate were controlled by mass flow controls (MFC). At the outlet of the reactor, a water trap was used to quantify periodically water formed during the reaction. Outlet gas composition was measured by a $\mu-G C$ (MyGC, Agilent). A gas counter was also used to measure the total outlet gas flow rate, which was used for the calculation of reaction conversion and selectivity.

The main products of the reaction were $\mathrm{CO}$ and $\mathrm{H}_{2}$. Water and coke were identified as by product. The quantification of $\mathrm{CO}, \mathrm{H}_{2}$ and $\mathrm{H}_{2} \mathrm{O}$ could be done during the reaction while it was not possible for coke. Thus, the reaction conversion and the selectivity in $\mathrm{CO}, \mathrm{H}_{2}, \mathrm{H}_{2} \mathrm{O}$, and solid carbon, as well as the molar ratio of $\mathrm{H}_{2} / \mathrm{CO}$ were calculated by the following formula.

$$
\begin{aligned}
& \mathrm{CH}_{4} \text { conversion }(\%)=\frac{\dot{\mathrm{Q}}_{\left(\mathrm{CH}_{4}\right) \text { in }}-\dot{\mathrm{Q}}_{\left(\mathrm{CH}_{4}\right)_{\text {out }}}}{\dot{\mathrm{Q}}_{\left(\mathrm{CH}_{4}\right)_{\text {in }}}} \mathrm{x} 100 \\
& \mathrm{CO}_{2} \text { conversion }(\%)=\frac{\dot{\mathrm{Q}}_{\left(\mathrm{CO}_{2}\right)_{\text {in }}}-\dot{\mathrm{Q}}_{\left(\mathrm{CO}_{2}\right)_{\text {out }}}}{\dot{\mathrm{Q}}_{\left(\mathrm{CO}_{2}\right)_{\text {in }}}} \times 100 \\
& \mathrm{CO} \text { selectivity }(\%)=\frac{\dot{\mathrm{Q}}_{\mathrm{O}(\mathrm{CO} \text { produced })}}{\dot{\mathrm{Q}}_{\mathrm{O}(\mathrm{CO} \text { consummed })}} \times 100 \\
& \mathrm{H}_{2} \text { selectivity }(\%)=\frac{\dot{\mathrm{Q}}_{\mathrm{H}(\mathrm{H} \text { 2produced })}}{\dot{\mathrm{Q}}_{\mathrm{H}(\mathrm{CH} \text { consumed })}} \mathrm{x} 100
\end{aligned}
$$$$
\mathrm{H}_{2} \mathrm{O} \text { selectivity }(\%)=\frac{\dot{\mathrm{Q}}_{\mathrm{O}(\mathrm{H} 2 \mathrm{O} \text { produced })}}{\dot{\mathrm{Q}}_{\mathrm{O}(\mathrm{CO} 2 \text { consummed })}} \times 100
$$$$
\mathrm{C}_{(\mathrm{s})} \text { selectivity }(\%)=\frac{\dot{\mathrm{Q}}_{\mathrm{Cs}(\mathrm{out})}}{\left(\dot{\mathrm{Q}}_{\mathrm{C}(\mathrm{CH} 4 \text { consumed })}+\dot{\mathrm{Q}}_{\mathrm{C}(\mathrm{CO} \text { consumed })}\right)} \mathrm{x} 100
$$

$\mathrm{H}_{2} / \mathrm{CO}=\frac{\% \mathrm{H}_{2}}{\% \mathrm{CO}}$

where $\dot{\mathrm{Q}}_{\left(\mathrm{CH}_{4}\right) \text { in }}$ and $\dot{\mathrm{Q}}_{\left(\mathrm{CH}_{4}\right)_{\text {out }}}$ : methane molar flow rate $\left(\mathrm{mmol} \mathrm{h}^{-1}\right)$ at the reactor inlet and outlet; $\dot{\mathrm{Q}}_{\left(\mathrm{CO}_{2}\right)_{\text {in }}}$ and $\dot{\mathrm{Q}}_{\left(\mathrm{CO}_{2}\right)_{\text {out }}}$ : carbon dioxide molar flow rate $\left(\mathrm{mmol} \mathrm{h}^{-1}\right)$ at the reactor inlet and outlet; $\dot{\mathrm{Q}}_{\mathrm{O} \text { (H2O produced) and }}$ $\dot{\mathrm{Q}}_{\mathrm{O} \text { (CO2consummed): }}$ atomic oxygen flow rate $\left(\mathrm{mmol} \mathrm{h}^{-1}\right)$ at the reactor inlet (under $\mathrm{H}_{2} \mathrm{O}$ form) and outlet (under $\mathrm{CO}_{2}$ form); $\dot{\mathrm{Q}}_{\mathrm{O} \text { (Co produced) }}$ : atomic oxygen flow rate $\left(\mathrm{mmol} \mathrm{h}^{-1}\right)$ at the reactor outlet (under $\mathrm{CO}$ form); $\dot{\mathrm{Q}}_{\mathrm{H}(\mathrm{H} 2 \text { produced })}$ and $\dot{\mathrm{Q}}_{\mathrm{H}(\mathrm{CH} 4 \mathrm{consumed})}$ : atomic hydrogen flow rate $\left(\mathrm{mmol} \mathrm{h}^{-1}\right.$ ) at the reactor inlet (under $\mathrm{H}_{2}$ form) and outlet (under $\mathrm{CH}_{4}$

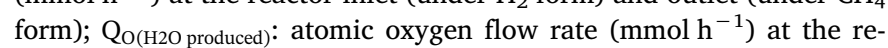
actor outlet (under $\mathrm{H}_{2} \mathrm{O}$ form).

\section{Results}

\subsection{Catalyst characterization}

Table 2 shows ICP-AES and specific surface area results. The initial HAP support used in this work had the molar ratio of Ca to P of 1.7, which is close to the stoichiometry of calcium hydroxyapatite $(\mathrm{Ca} /$ $\mathrm{P}=10 / 6$ or 1.67). The contents of nickel and cobalt in the final
Table 2

Elemental analysis and specific surface area of the prepared catalysts.

\begin{tabular}{lllll}
\hline Catalyst & Co (wt.\%) & Ni (wt.\%) & Ca/P & $\mathrm{S}_{\mathrm{BET}}\left(\mathrm{m}^{2} / \mathrm{g}\right)$ \\
\hline Ni-Co/HAP_SIWI & 2.4 & 2.4 & 1.7 & 46 \\
Co-Ni/HAP_SIWI & 2.6 & 2.8 & & 49 \\
Ni-Co/HAP_COI & 2.8 & 2.6 & & 48 \\
HAP support & 0 & 0 & & 60 \\
\hline
\end{tabular}

Table 3

Deactivation rates of the hydroxyapatite-based catalysts.

\begin{tabular}{lll}
\hline Catalyst & $\begin{array}{l}\text { Deactivation rate }\left(\% \mathrm{~h}^{-1}\right) \text { at } \\
\text { TOS }=6 \mathrm{~h}\end{array}$ & $\begin{array}{l}\text { Deactivation rate }\left(\% \mathrm{~h}^{-1}\right) \text { at } \\
\text { TOS }=50 \mathrm{~h}\end{array}$ \\
\hline Ni-Co/HAP_SIWI & 2.13 & 0.23 \\
Co-Ni/HAP_SIWI & 1.15 & 0.32 \\
Ni-Co/HAP_COI & 1.45 & 0.23 \\
\hline
\end{tabular}

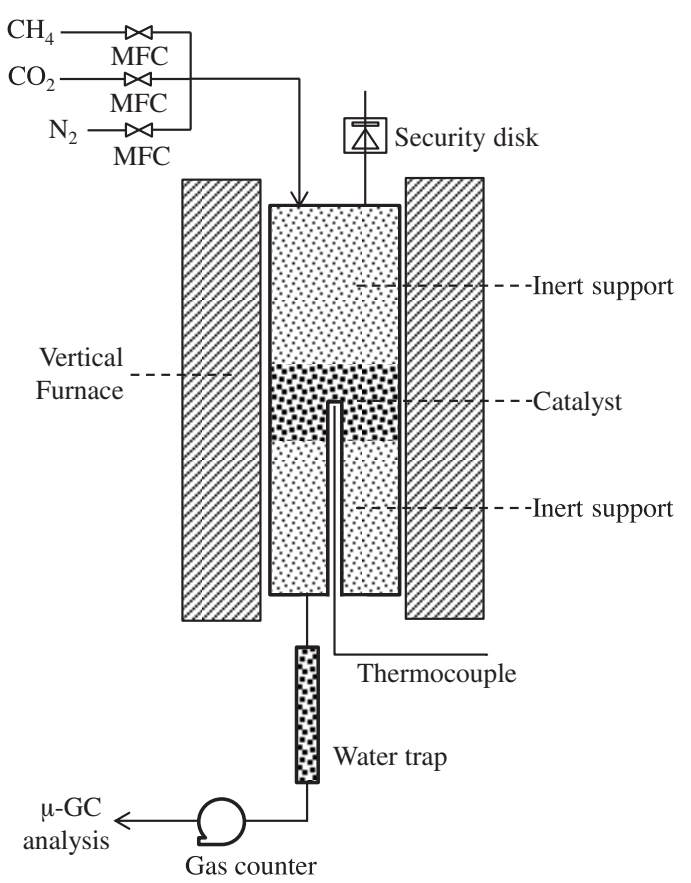

Fig. 1. Illustration of the fixed-bed reactor used in this work.

catalysts were also close to the theoretical value of $2.85 \mathrm{wt} . \%$. The difference must be due to metals deposition on the flask walls during the preparation. Metals deposition led to a small decrease of the specific surface area of the support.

XRD patterns of HAP support and HAP supported metals catalysts are presented in Fig. 2. The initial support had only hydroxyapatite as crystalline phase with the main diffraction peaks at $2 \theta$ of $25.9,31.8$, $32.2,32.9,46.8$ and $49.7^{\circ}$. NiO crystalline phase, which has the main diffraction peaks at 37.2 and $43.2^{\circ}$, was detected for Co-Ni/HAP_COI, which was prepared by co-impregnation method. The average crystallite size of $\mathrm{NiO}$ of this catalyst was estimated at $11 \mathrm{~nm}$. CaO crystalline phase (with the main peak at $37.0^{\circ}$ ) was also observed for this co-impregnated catalyst. $\mathrm{Co}_{3} \mathrm{O}_{4}$ crystalline phase (with the main diffraction peaks at $36.7^{\circ}$ ) appeared in all three catalysts. The estimation of the average crystallite size of $\mathrm{CaO}$ and $\mathrm{Co}_{3} \mathrm{O}_{4}$ of the prepared catalysts is difficult because their main diffraction peaks were very close to each other, and were also close to the second diffraction peak of NiO. Finally, all three catalysts contained also new crystalline phase of cobalt exchanged hydroxyapatite $\left(\mathrm{Ca}_{10-\mathrm{x}} \mathrm{Co}_{\mathrm{x}}\left(\mathrm{PO}_{4}\right)_{6}(\mathrm{OH})_{2}\right)$ and nickel exchanged hydroxyapatite $\left(\mathrm{Ca}_{10-\mathrm{x}} \mathrm{Ni}_{\mathrm{x}}\left(\mathrm{PO}_{4}\right)_{6}(\mathrm{OH})_{2}\right)$.

The formation of $\mathrm{CaO}, \mathrm{Ca}_{10-\mathrm{x}} \mathrm{Co}_{\mathrm{x}}\left(\mathrm{PO}_{4}\right)_{6}(\mathrm{OH})_{2}$, and $\mathrm{Ca}_{10}$ - 


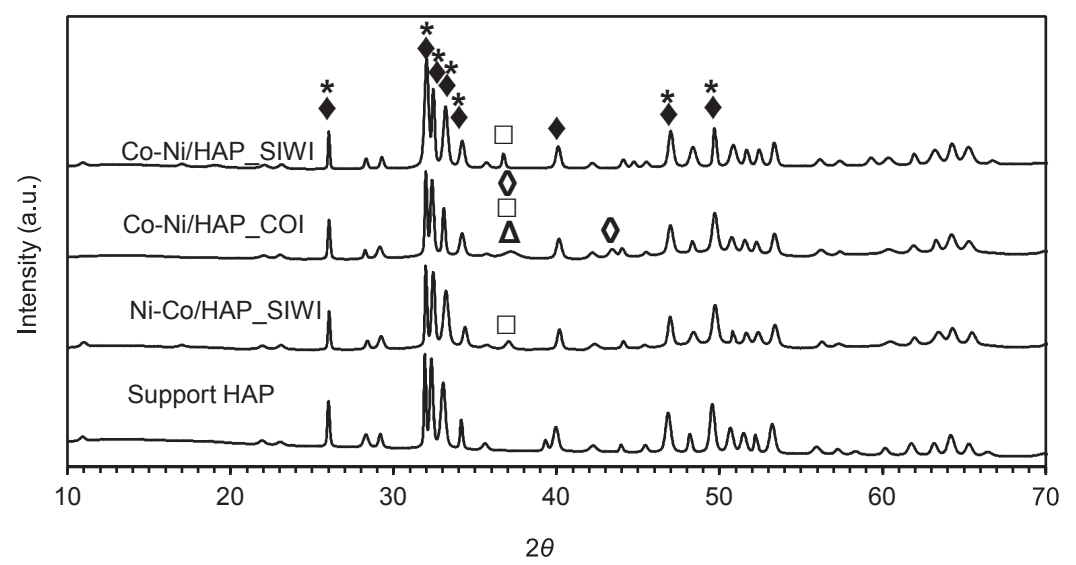

Fig. 2. XRD patterns of the prepared catalysts; $\$$ : HAP, *: cobalt and nickel exchanged hydroxyapatites, $\diamond$ : NiO, $\square: \mathrm{Co}_{3} \mathrm{O}_{4}, \Delta$ : $\mathrm{CaO}$.
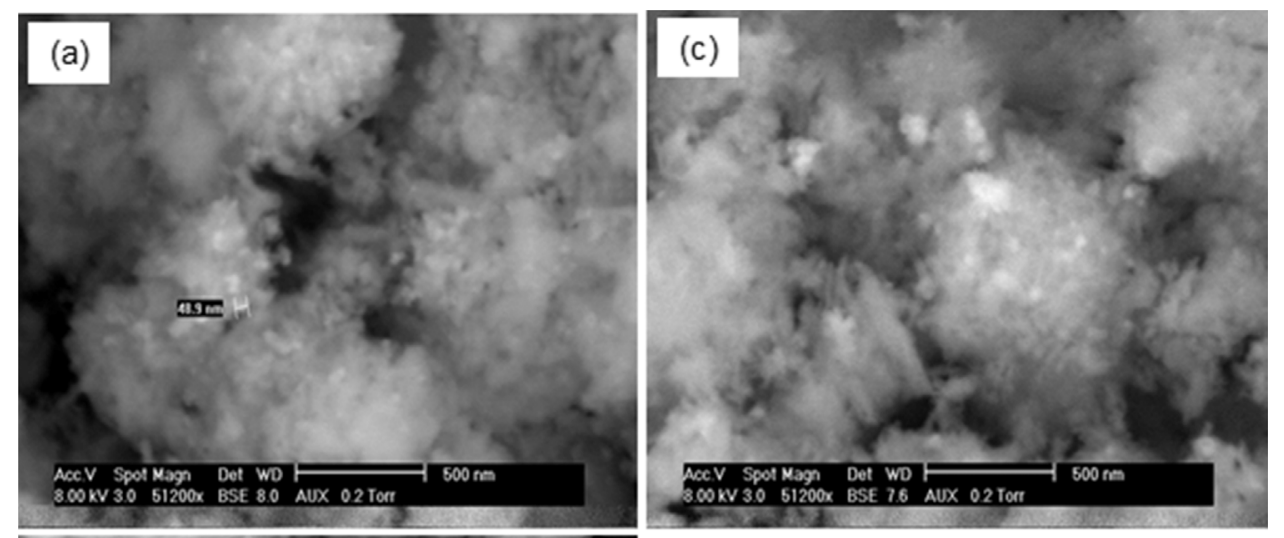

Fig. 3. SEM images of: (a) Co-Ni/HAP_SIWI; (b) NiCo/HAP_SIWI; (c) Ni-Co/HAP_COI; and (d) support HAP.
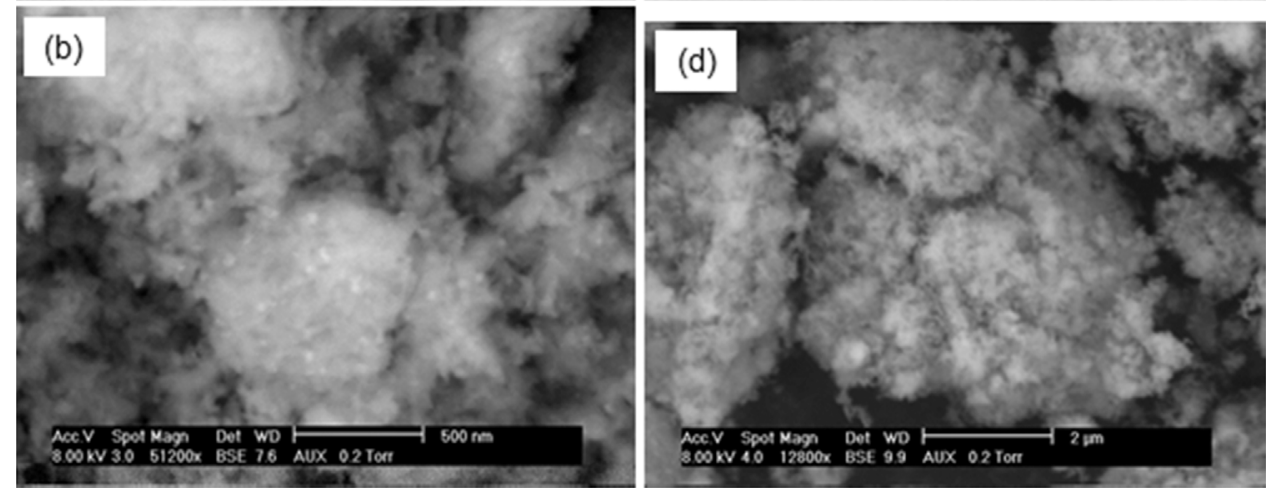

${ }_{\mathrm{x}} \mathrm{Ni}_{\mathrm{x}}\left(\mathrm{PO}_{4}\right)_{6}(\mathrm{OH})_{2}$ could be explained by the cationic exchange capacity of HAP. In fact, HAP is well known for its capacity to replace $\mathrm{Ca}^{2+}$ cations in its apatitic structure by other divalent cations such as $\mathrm{Pb}^{2+}$, $\mathrm{Ni}^{2+}, \mathrm{Co}^{2+}, \mathrm{Cd}^{2+} \ldots$ in an aqueous suspension $[40,41]$. The cationic exchanges with $\mathrm{Ni}^{2+}$ and $\mathrm{Co}^{2+}$ can be illustrated by the following equations:

$\mathrm{Ca}_{10}\left(\mathrm{PO}_{4}\right)_{6}(\mathrm{OH})_{2}+\mathrm{xNi}\left(\mathrm{NO}_{3}\right)_{2} \rightarrow \mathrm{Ca}_{10-\mathrm{x}} \mathrm{Ni}_{\mathrm{x}}\left(\mathrm{PO}_{4}\right)_{6}(\mathrm{OH})_{2}+\mathrm{xCa}\left(\mathrm{NO}_{3}\right)_{2}$

$\mathrm{Ca}_{10}\left(\mathrm{PO}_{4}\right)_{6}(\mathrm{OH})_{2}+\mathrm{xCo}\left(\mathrm{NO}_{3}\right)_{2} \rightarrow \mathrm{Ca}_{10-\mathrm{x}} \mathrm{Co}_{\mathrm{x}}\left(\mathrm{PO}_{4}\right)_{6}(\mathrm{OH})_{2}+\mathrm{xCa}\left(\mathrm{NO}_{3}\right)_{2}$

Probably during the incipient wetness impregnation, the cationic exchange took place leading to the formation of cobalt and nickel exchange hydroxyapatites, as well as the liberation of $\mathrm{Ca}\left(\mathrm{NO}_{3}\right)_{2}$ (Eqs. (9) \& (10)). $\mathrm{Ca}\left(\mathrm{NO}_{3}\right)_{2}$ decomposed during calcination to form $\mathrm{CaO}$ (Eq. (11)).

$2 \mathrm{Ca}\left(\mathrm{NO}_{3}\right)_{2} \rightarrow 2 \mathrm{CaO}+4 \mathrm{NO}_{2}+\mathrm{O}_{2}$
The formation of $\mathrm{CaO}$ was only detected by XRD for the catalysts prepared by co-impregnation method. The aqueous solution containing both nickel and cobalt nitrates used for co-impregnation could be more acidic than those containing only nickel or cobalt nitrate used for successive impregnation. High acidity could lead to a local surface dissolution of HAP layers, thus favor the cationic exchange between $\mathrm{Ca}^{2+}$ and $\mathrm{Ni}^{2+}$ and $\mathrm{Co}^{2+}$. However, $\mathrm{CaO}$ could be possibly formed for the two catalysts prepared by successive impregnation but its content was not enough for XRD detection.

SEM images of the fresh catalysts (after calcination) are presented in Fig. 3. For the catalyst prepared by cobalt deposition followed by nickel deposition (Fig. 3(a)), SEM allowed identifying metal-based particles (oxides) with particle size of dozens $\mathrm{nm}$. These particles seemed to be well distributed on the surface of the HAP support. Similar results were observed with the catalyst prepared by nickel deposition followed by cobalt deposition (Fig. 3(b)). For the catalyst prepared by co-impregnation method, it seemed that metal-based particles of larger size were formed (Fig. 3(c)). In all case, metal deposition did not affect the morphology of HAP support. 

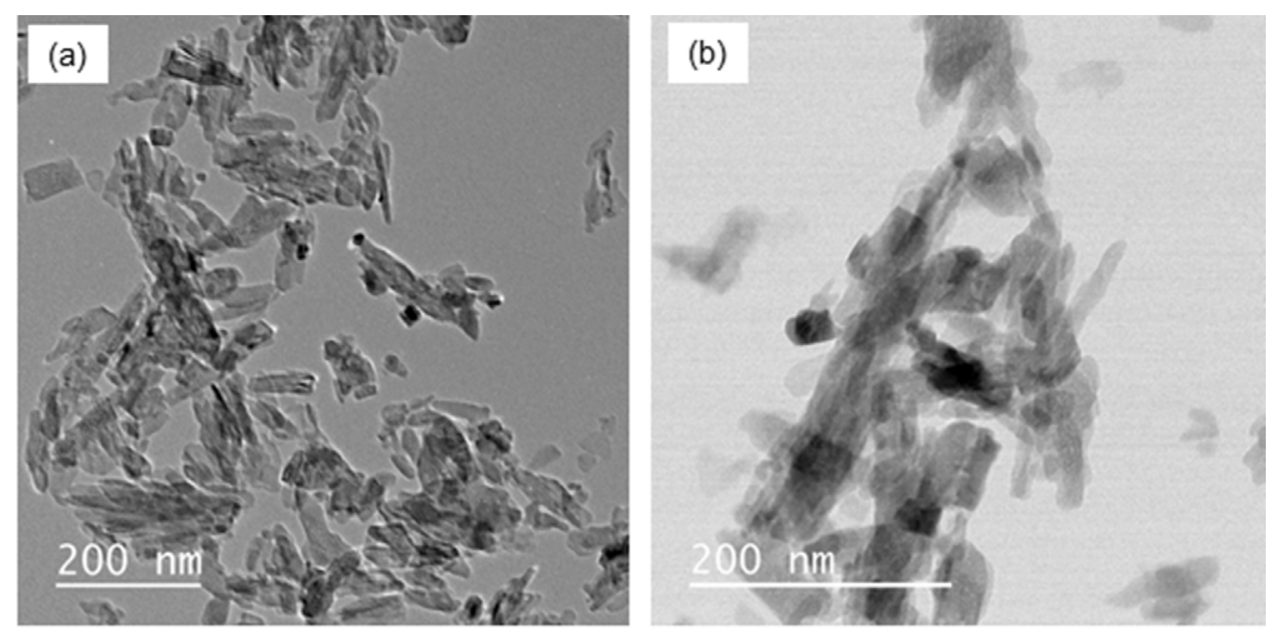

Fig. 4. TEM images of: (a, b) Co-Ni/HAP_SIWI; (c, d) $\mathrm{Ni-Co/HAP}$ SIWI; and (e, f) Ni-Co/HAP_COI.
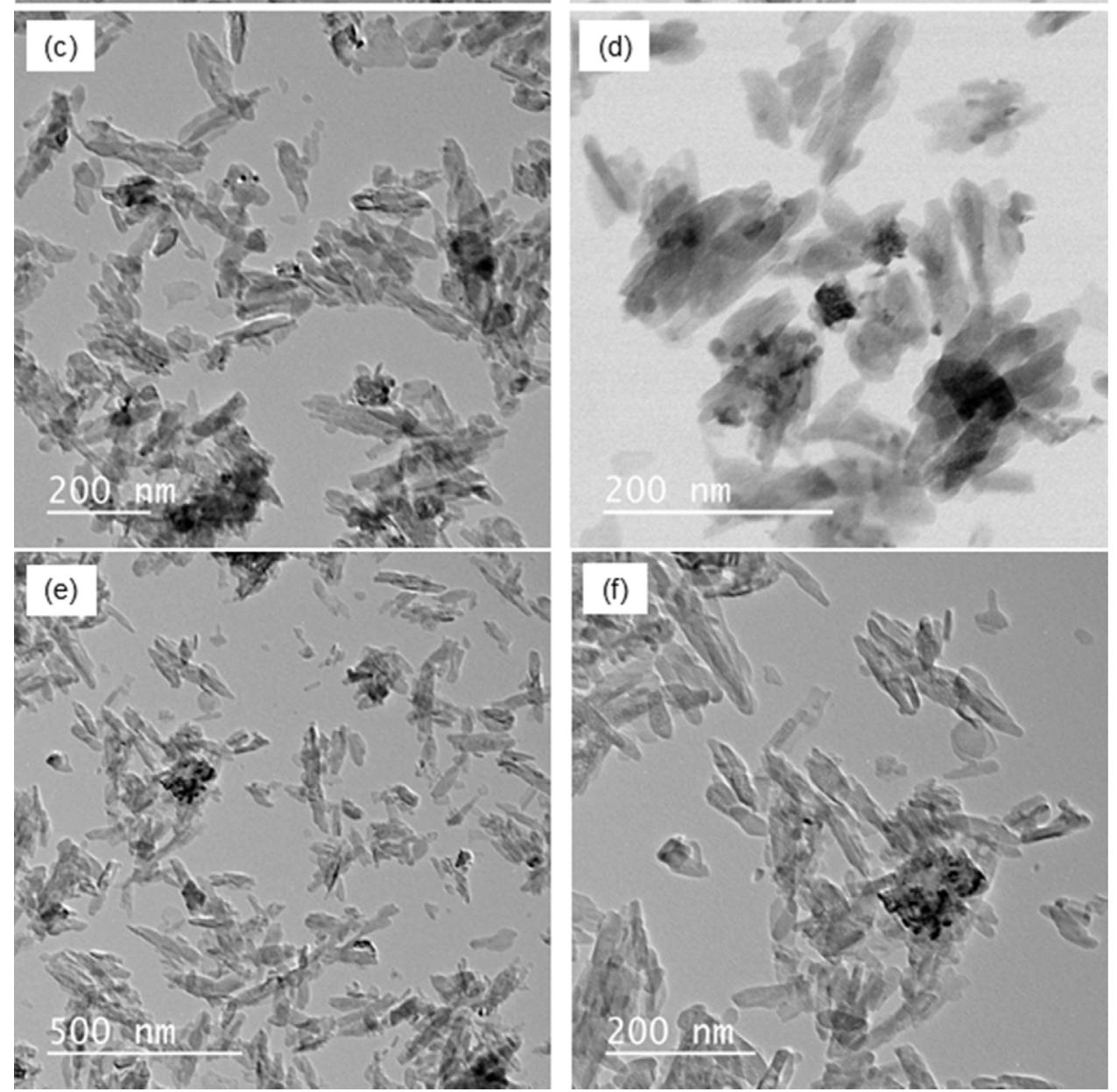

To evaluate the distribution of Ni- and Co-based particles on the support surface, TEM-EDX coupling was performed on the fresh catalysts. Fig. 4 shows TEM images of all three catalysts which confirmed SEM results presented above. From TEM images, particle size distribution was also evaluated using Image $J$ software and the results are later shown in Fig. 11. Metal oxides particles of dozens nm were observed for all the prepared fresh catalysts which were similar to each other. They were also well distributed on the surface of the support.

To identify the distribution of each active metal on the support surface of the fresh catalysts, imaging of the main elements was performed with an EDX analyzer. Fig. 5 shows an example of EDX spot analysis on the catalyst prepared by nickel deposition followed by cobalt deposition and calcination. All spot analyses on bright metal-based particles demonstrated the presence of both $\mathrm{Ni}$ and Co (i.e. spots 001 and 002). This demonstrates the formation of "bi-metallic particles" with the simultaneous presence of the two active metals under oxides form. On dark particles (surface support), no trace of $\mathrm{Ni}$ or Co was observed (i.e. spot 003).

Fig. 6 shows an example of cartography of the main elements present in the catalyst Ni-Co/HAP_SIWI. As expected, $\mathrm{Ca}, \mathrm{P}$ and $\mathrm{O}$ were observed as the three main elements of the HAP support. Most of Niand Co-based particles detected by EDX analysis were found to be superimposed to each other. This suggests the formation of bimetallic NiCo particles (yellow arrows in Fig. 6(e) and (f)). This catalyst was prepared by the successive impregnation method. Since nickel and cobalt have similar physico-chemical properties, nickel particles formed 


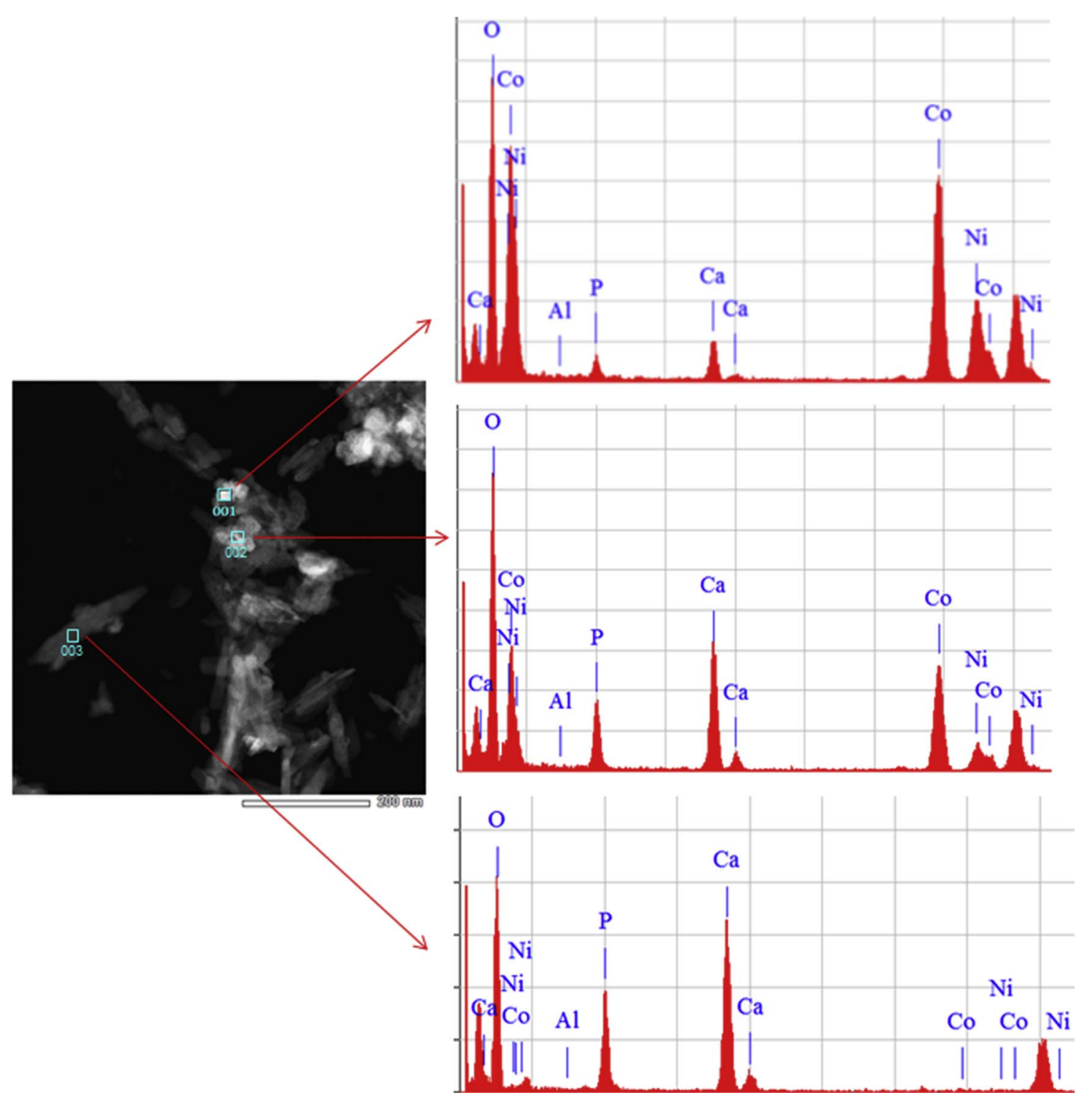

Fig. 5. Example of EDX analysis of Ni-Co/HAP_SIWI.

from the first deposition could promote and orientate the deposition and formation of cobalt particles during the second deposition. The superimposition of $\mathrm{Ni}$ and $\mathrm{Co}$ was also observed with the two other catalysts (Supporting information 2 and 3). Thus, the deposition order did not influence the formation of bimetallic Ni-Co particles.

\subsection{Catalytic performance}

Fig. 7 compares the catalytic activity of three catalysts under the same reaction conditions. The two catalysts prepared by SIWI method had the similar catalytic behavior with the comparable $\mathrm{CH}_{4}$ and $\mathrm{CO}_{2}$ conversions along the reaction. Both catalysts showed high initial catalytic activity (around 73-78\%). Then, a deactivation was observed within the first ten hours of reaction. Finally, the reactivity seemed to be relatively stable at around $60 \%$ for $\mathrm{CH}_{4}$ conversion and $68 \%$ for $\mathrm{CO}_{2}$ conversion. For the catalyst prepared by co-impregnation method, the initial conversion of $\mathrm{CH}_{4}$ and $\mathrm{CO}_{2}$ were lower (around 60\%) compared to those of the two other catalysts (around 73-78\%). Then, the catalytic activity of this catalyst also became stable at around $47 \%$ for $\mathrm{CH}_{4}$ conversion and $50 \%$ for $\mathrm{CO}_{2}$ conversion. XRD results presented above showed diffraction peaks of $\mathrm{CaO}$ which resulted from the partial cationic exchange between $\mathrm{Ca}^{2+}$ and $\mathrm{Ni}^{2+}$ and $\mathrm{Co}^{2+}$ for the co- impregnated catalyst (Fig. 2). It is well known that metallic Co and $\mathrm{Ni}$ were active for reforming reactions. On the other hand, exchanged $\mathrm{Ni}^{2+}$ and $\mathrm{Co}^{2+}$ in the rigid apatitic strucure $\left(\mathrm{Ca}_{10-\mathrm{x}} \mathrm{Ni}_{\mathrm{x}}\left(\mathrm{PO}_{4}\right)_{6}(\mathrm{OH})_{2}\right.$ and $\mathrm{Ca}_{10}$ $\left.{ }_{\mathrm{x}} \mathrm{Co}_{\mathrm{x}}\left(\mathrm{PO}_{4}\right)_{6}(\mathrm{OH})_{2}\right)$ were not active in DRM reaction as confirmed by additional catalytic tests (results not shown). Thus, Ni-Co/HAP_COI catalyst prepared by co-impregnation was less active than two other catalysts prepared by successive impregnation.

The catalytic performance of the prepared bimetallic Co-Ni catalysts in this work was roughly comparable with that of the hydroxyapatite supported monometallic nickel catalyst reported by Rêgo de Vasconcelos et al. under the similar experimental conditions [42].

Table 3 shows the deactivation rates of each catalyst for $6 \mathrm{~h}$ and $50 \mathrm{~h}$ of time-on-stream (TOS). As expected, the deactivation rates of all three catalysts was relatively low during $50 \mathrm{~h}$ of TOS $\left(0.23-0.32 \% \mathrm{~h}^{-1}\right)$, which emphasizes the high performance of the bimetallic hydroxyapatite catalysts. The deactivation of these catalysts was higher within the first $6 \mathrm{~h}$ of TOS $\left(1.15-2.13 \% \mathrm{~h}^{-1}\right)$, especially for the Ni-Co/ HAP_SIWI catalyst $\left(2.13 \% \mathrm{~h}^{-1}\right)$. The deactivation of the catalysts might be related to different aspects such as coke deposition and sintering. These aspects will be addressed later in the manuscript.

Fig. 8 shows the selectivity of the reaction into $\mathrm{H}_{2}, \mathrm{CO}, \mathrm{H}_{2} \mathrm{O}$, and the molar ratio of $\mathrm{H}_{2}$ to $\mathrm{CO}$. In all cases, the selectiviy was roughly stable in 

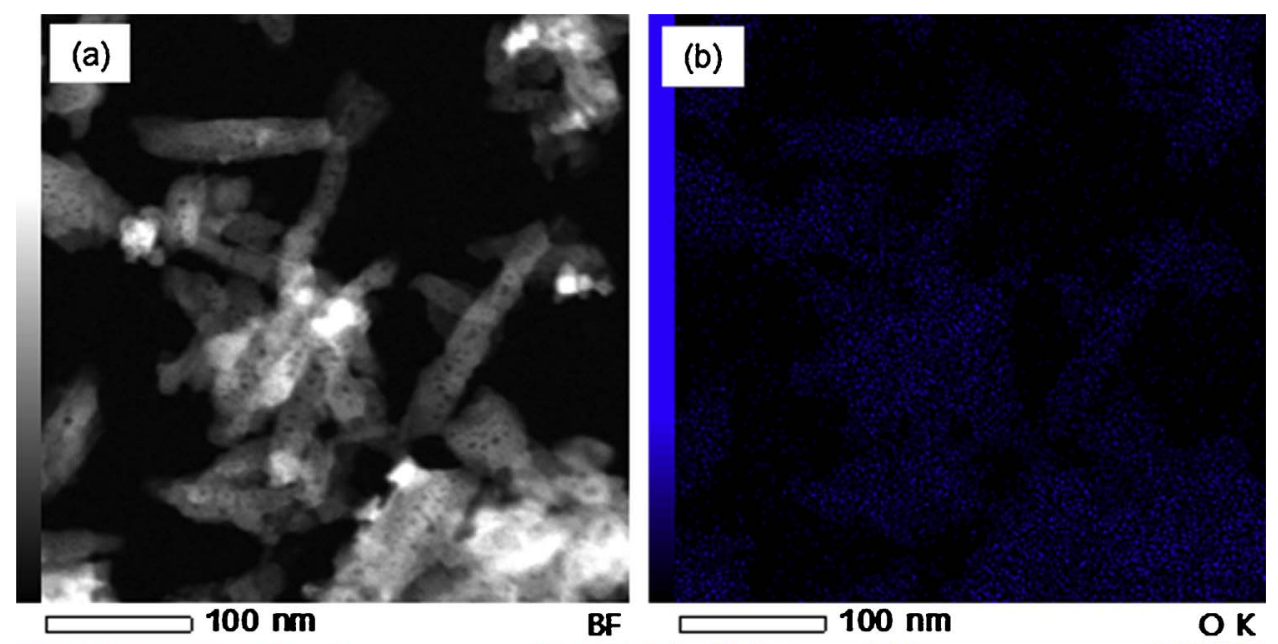

Fig. 6. Imaging of the main elements present in the catalyst Ni-Co/HAP_SIWI; (a): TEM image of the cartography zone; (b), (c), (d), (e), (f): imaging of $\mathrm{O}$, $\mathrm{Ca}, \mathrm{P}, \mathrm{Co}, \mathrm{Ni}$, respectively.
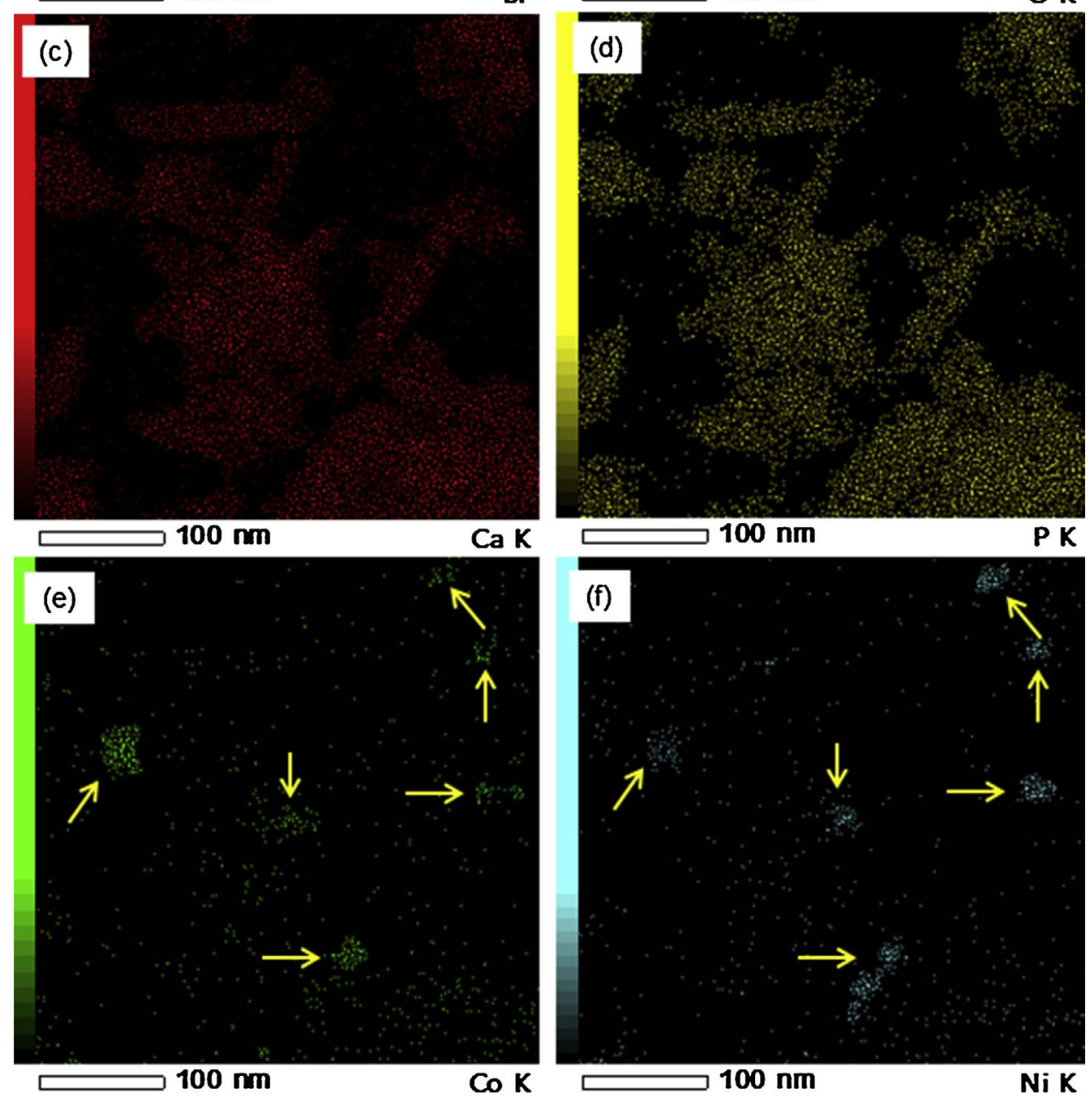

the range of $80-90 \%$ for $\mathrm{H}_{2}$ and $\mathrm{CO}$, and $10-20 \%$ for $\mathrm{H}_{2} \mathrm{O}$. In the literature [43,44], Ni- and Co-based catalysts usually had high selectivity into $\mathrm{H}_{2}$ and $\mathrm{CO}$ as found in this work. For both $\mathrm{H}_{2}$ and $\mathrm{CO}$ selectivity, the catalyst prepared by the co-impregnation method was more selective (around 90\%) than the catalysts prepared by the successive impregnation method (around 83-86\%). These high $\mathrm{H}_{2}$ and $\mathrm{CO}$ selectivity of Ni-Co/HAP COI catalyst must be due to its physico-chemical and structural properties. As mentioned above, Ni-Co/HAP_COI prepared by co-impregnation was different from two other catalysts prepared by successive impregnation, mostly with the presence of diffraction peaks of calcium oxide, resulting from the cationic exchange between $\mathrm{Ca}^{2+}$ and $\mathrm{Ni}^{2+}$ and $\mathrm{Co}^{2+}$. The presence of calcium oxide might have some beneficial effects on the selectivity of the reaction. Previous work of Bellido et al. [45] showed that the addition of $\mathrm{CaO}$ to $\mathrm{Ni} / \mathrm{ZrO}_{2}$ catalysts allowed decreasing the implication of $\mathrm{CO}_{2}$ in RWGS reaction, as well as limiting coke deposition from Boudouard reaction or methane cracking. This improves $\mathrm{H}_{2}$ and $\mathrm{CO}$ selectivity. The beneficial effect of $\mathrm{CaO}$ addition on $\mathrm{H}_{2}$ and $\mathrm{CO}$ selectivity in DRM reaction was also highlighted in other works using nickel as active metal $[46,47]$.

About the $\mathrm{H}_{2}$ to $\mathrm{CO}$ morar ratio, its evolution was similar for all three catalysts. This ratio decreased within the first $20 \mathrm{~h}$ of reaction from roughly $100 \%$ to appromaxively $90 \%$ and was then stable at this value. The initial decrease in the $\mathrm{H}_{2} / \mathrm{CO}$ ratio might be related to the occurrence of Boudouard reaction (Eq. (12)) and of RWGS (Eq. (13)). 

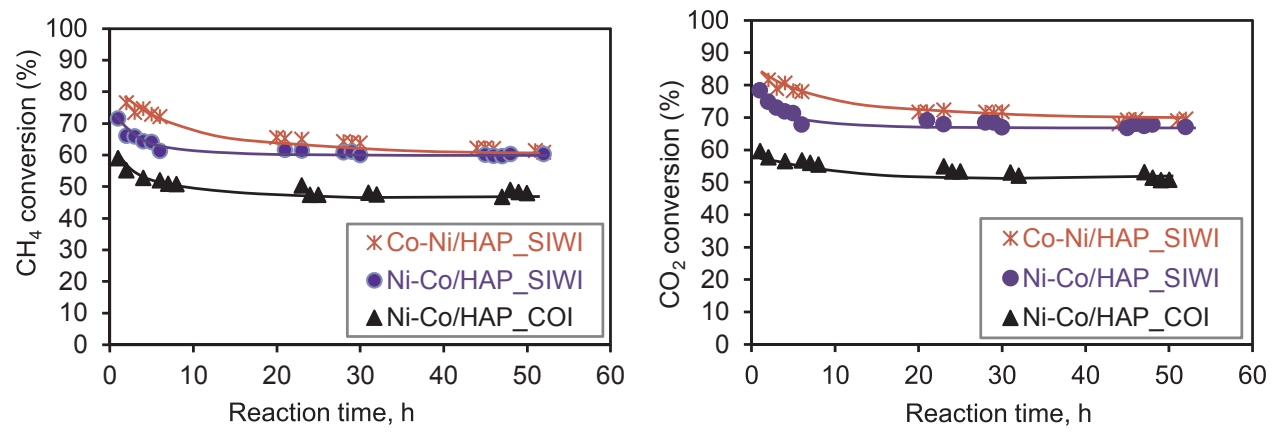

Fig. 7. Reaction conversions at $700{ }^{\circ} \mathrm{C}$ obtained with different catalysts; gas flow rate of $\mathrm{CH}_{4}, \mathrm{CO}_{2}$ and $\mathrm{Ar}$ : 20,20 and $50 \mathrm{NmL} / \mathrm{min}$, respectively; $340 \mathrm{mg}$ of catalyst.
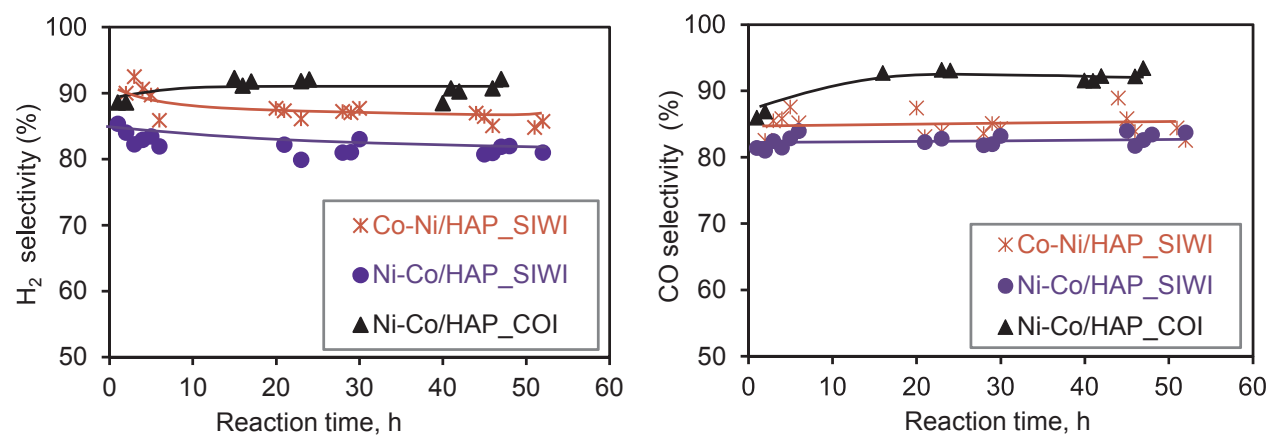

Fig. 8. Reaction selectivity at $700{ }^{\circ} \mathrm{C}$ obtained with different catalysts; gas flow rate of $\mathrm{CH}_{4}, \mathrm{CO}_{2}$ and $\mathrm{Ar}$ : 20,20 and $50 \mathrm{NmL} / \mathrm{min}$, respectively; $340 \mathrm{mg}$ of catalyst.
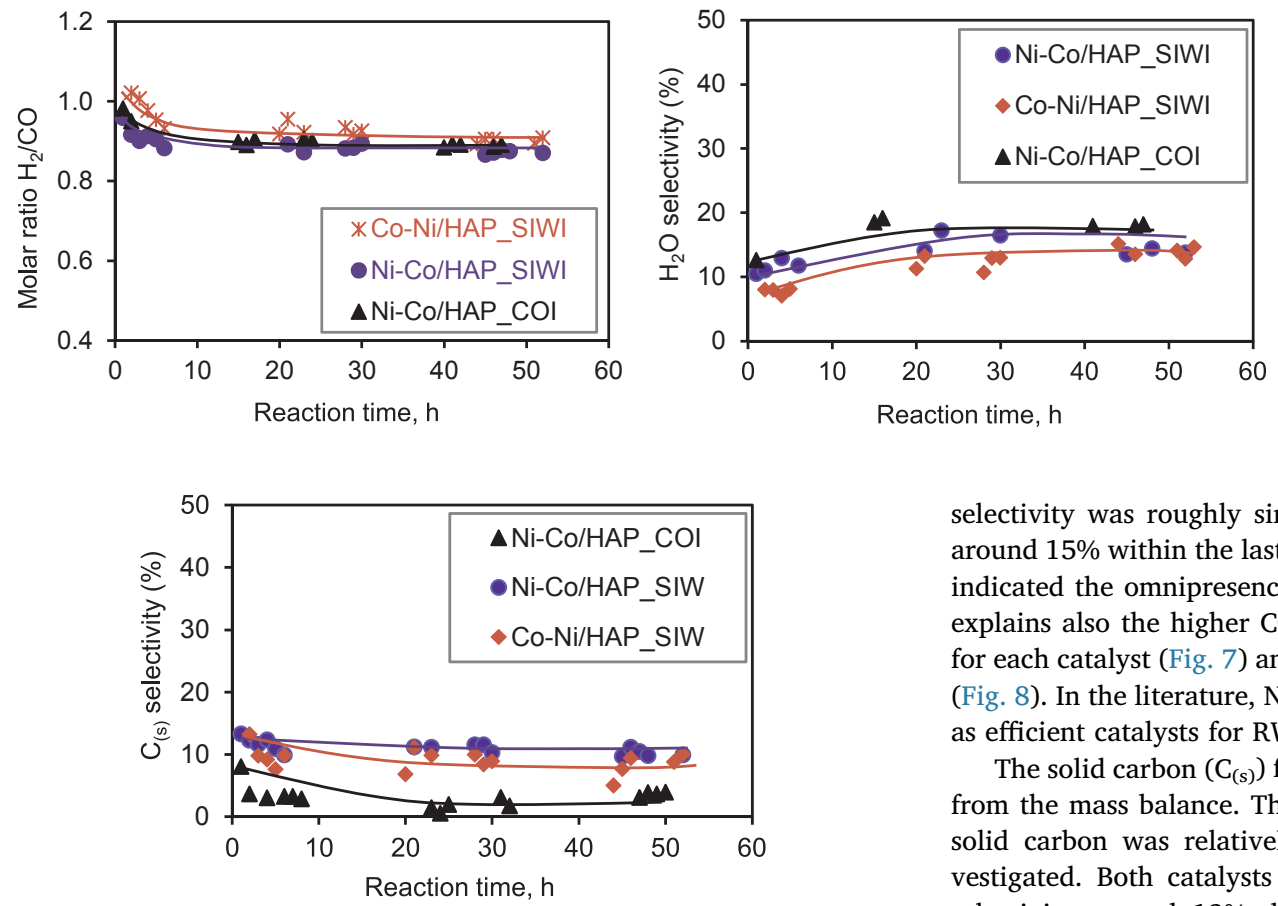

Fig. 9. Solid carbon selectivity at $700{ }^{\circ} \mathrm{C}$ obtained with different catalysts; gas flow rate of $\mathrm{CH}_{4}, \mathrm{CO}_{2}$ and $\mathrm{N}_{2}: 20,20$ and $50 \mathrm{NmL} / \mathrm{min}$, respectively; $340 \mathrm{mg}$ of catalyst.

$$
\begin{aligned}
& 2 \mathrm{CO} \rightarrow \mathrm{CO}_{2}+\mathrm{C} \\
& \mathrm{CO}_{2}+\mathrm{H}_{2} \rightarrow \mathrm{CO}+\mathrm{H}_{2} \mathrm{O}
\end{aligned}
$$

Despite numerous papers on DRM reaction in the literature, no study reported the experimental quantification of water as a by-product. Water formation was only deduced from the quantification of $\mathrm{H}_{2}$, $\mathrm{CO}, \mathrm{CO}_{2}$ and $\mathrm{CH}_{4}$ at the reactor outlet $[44,48]$. The reactor setup used in this work (Fig. 1) allowed measuring water content formed along the catalytic reaction, as shown in Fig. 8. Under the experimental conditions used in this work, water formation from RWGS (Eq. (13)) is inevitable as predicted by thermodynamic calculation [13,49]. The water

selectivity was roughly similar for all three catalysts and was stable around $15 \%$ within the last $30 \mathrm{~h}$ of reaction. This high amount of water indicated the omnipresence of RWGS for these catalytic systems. This explains also the higher $\mathrm{CO}_{2}$ conversion compared to $\mathrm{CH}_{4}$ conversion for each catalyst (Fig. 7) and the molar ratio of $\mathrm{H}_{2}$ to $\mathrm{CO}$ smaller than 1 (Fig. 8). In the literature, Ni- and Co-based catalysts were well reported as efficient catalysts for RWGS [50,51].

The solid carbon $\left(\mathrm{C}_{(\mathrm{s})}\right)$ formed during the reaction could be deduced from the mass balance. The results are shown in Fig. 9. Selectivity to solid carbon was relatively low $(<13 \%)$ for all three catalysts investigated. Both catalysts prepared by SIWI method showed carbon selectivity around $13 \%$ during $50 \mathrm{~h}$ of TOS. However, the catalyst prepared by the co-impregnation method (Ni-Co/HAP_COI) showed initial carbon selectivity around $8 \%$, which decreased to $4 \%$ during the last $25 \mathrm{~h}$ of TOS. The decrease in the carbon selectivity is simultaneous to the increase in $\mathrm{CO}$ selectivity, which suggests the occurrence of the reverse Boudouard reaction, in which the solid carbon reacts with $\mathrm{CO}_{2}$ to form CO. These results also emphasize the high performance of the bimetallic hydroxyapatite catalysts. Indeed, there are several reports in the literature concerning the benefits of bimetallic Ni-Co catalysts. The formation of a Ni-Co alloy would enhance not only the catalytic activity but also the supression of carbon deposits during the reaction $[37,52,53]$.

TEM analysis of the used catalysts was also carried out. TEM results are illustrated in Fig. 10. In all cases, the used catalysts contained only few carbonaceous species on their surface. The growth of carbon 

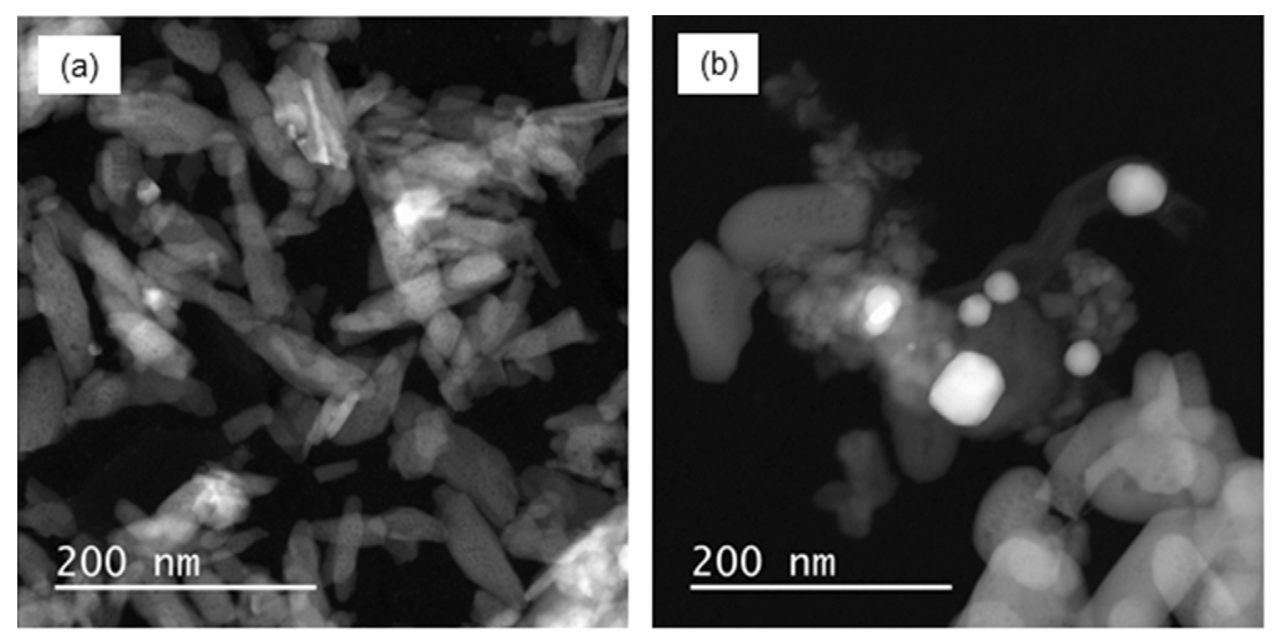

Fig. 10. TEM images the used catalysts recovered after DRM reaction at $700{ }^{\circ} \mathrm{C}:(\mathrm{a}$, b) $\mathrm{Co}-\mathrm{Ni}$ / HAP_SIWI; (c, d) Ni-Co/HAP_SIWI; and (e, f) Ni-Co/ HAP_COI.
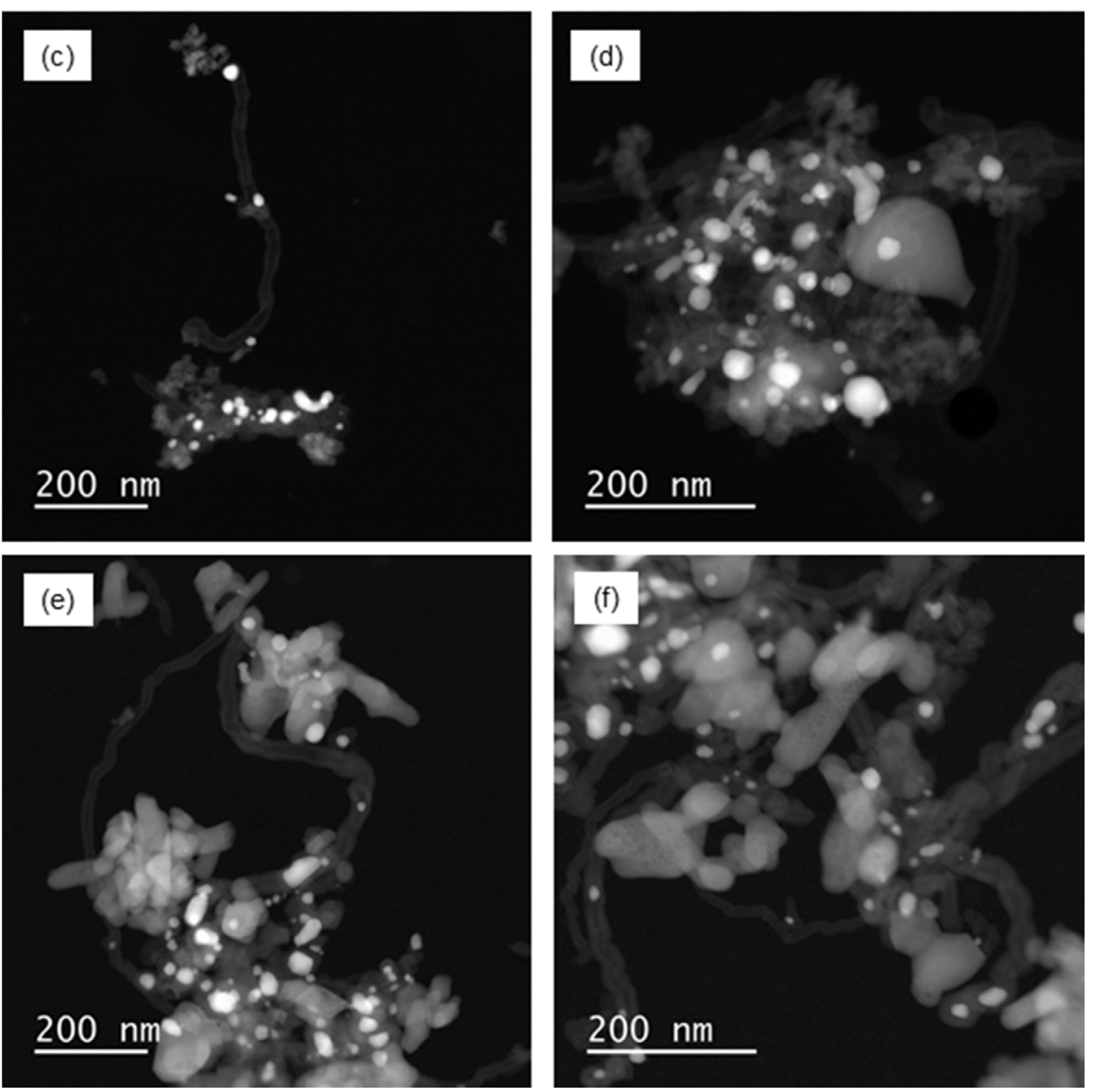

nanotubes (CNTs) was observed at low frequency compared to the results reported in the literature for DRM reaction [25,26,54]. In some cases, we can see the embedding of metals particles inside CNTs, causing the partial loss of the catalytic activity. Particularly, other kinds of carbon (i.e. core-shell carbon, amorphous carbon) leading to the embedding of metals particles and so the catalytic deactivation during DRM reaction [25,55,56], was rarely observed. This explained the catalytic stability of these catalysts.

Fig. 11 compares metals particle size of the prepared catalysts before and after catalytic tests at $700{ }^{\circ} \mathrm{C}$. We particularly note that for the fresh catalysts which were pre-treated by air calcination, TEM analysis showed the particle sizes of cobalt and nickel oxides. On the other hand, for the used catalysts, TEM analysis showed the particle sizes of metallic particles, which could be partially oxidized in free contact with air after DRM reaction. Co-Ni/HAP_SIWI (Fig. 11A) and Ni-Co/HAP_COI (Fig. 11B) fresh catalysts showed a $d_{50}$ of $10-20 \mathrm{~nm}$. However, after $50 \mathrm{~h}$ of TOS, the percentage of particles of more than $30 \mathrm{~nm}$ was relatively higher, which indicates that sintering/agglomeration of the active phase took place during the reaction. This decreased particles dispersion and, along with the carbon deposition, led to the initial deactivation of the catalysts in the first hours of TOS. On the other hand, Ni-Co/HAP_SIWI fresh catalyst showed higher percentage of particles around $20-30 \mathrm{~nm}$ and its distribution did not significantly changed after $50 \mathrm{~h}$ of TOS (Fig. 11C). This might also explain the very 

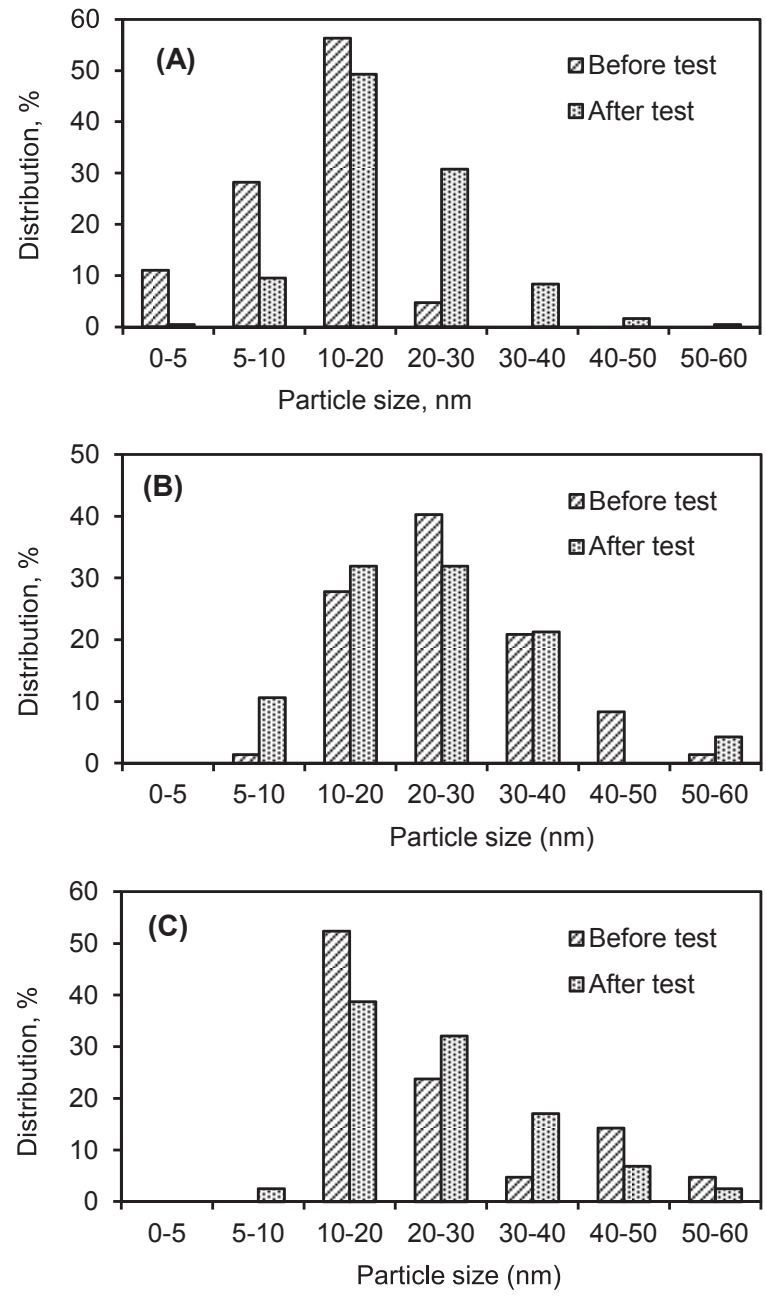

Fig. 11. Comparison of metals particle size distribution before and after catalytic test at $700{ }^{\circ} \mathrm{C}$; (A): Co-Ni/HAP_SIWI; (B) Ni-Co/HAP_SIWI; and (C) Ni-Co/HAP_COI.

low $\mathrm{C}_{(\mathrm{s})}$ selectivity presented by this catalyst. Indeed, it has been widely reported in the literature that small metal particles are less prone to carbon deposition $[57,58]$ and thus favors the catalyst stability. In all cases, the size of Ni-Co particles only slightly increased, which indicated that sintering of metal particles took place in a low extent. This explains also the overall catalytic stability observed during DRM reaction.

The high performance of the catalysts is related to its physicalchemical properties. The hydroxyapatite support gives thermal stability to the catalyst and its well-known basic properties helps coke removal through Boudouard reaction (Eq. (12)) [32,33,36,38]. Moreover, using an active phase composed of $\mathrm{Ni}$ and Co probably enhanced the catalyst activity and the suppression of carbon deposits. In fact, it has been widely reported in the literature that combining Co and Ni results in better metal dispersion and strong metal-support interaction, which enhances the coke resistance of the catalysts [38,59]. Further characterizations such as acido-basic titration, TPO, TPD and TG-MS coupling seem to be necessary to understand why bimetallic Ni-Co/HAP allowed limiting the formation of amorphous carbon during DRM reaction. Surface properties of HAP support such as its interaction with metals particles, its acido-basic properties need to be highlighted.

\subsection{DRM at $750^{\circ} \mathrm{C}$}

Previous study on the thermodynamic of DRM reaction showed that high reaction temperature favors the conversion of $\mathrm{CH}_{4}$ and $\mathrm{CO}_{2}$ and limits the deposition of carbonaceous species [13,49,60]. However,
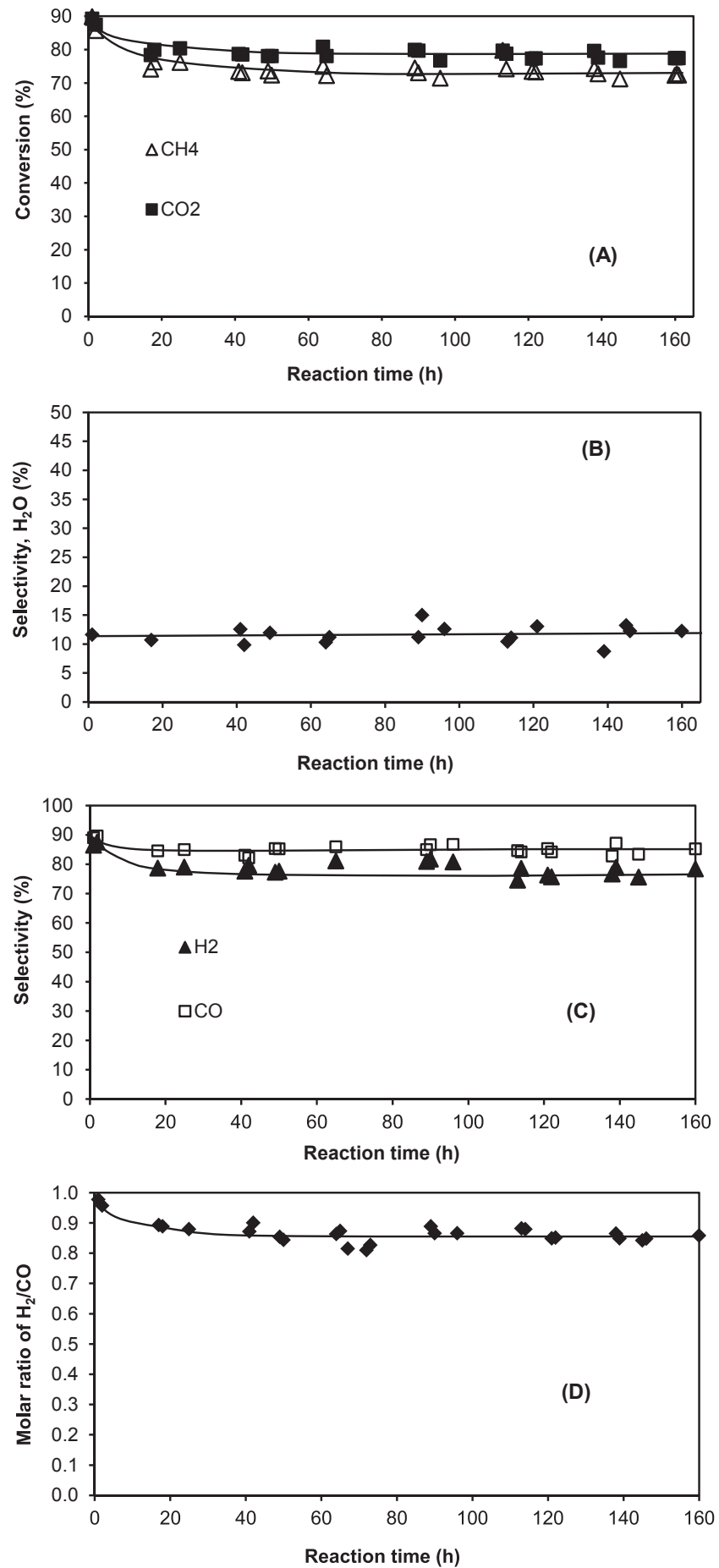

Fig. 12. Catalytic results obtained with Ni-Co/HAP_SIWI at $750{ }^{\circ} \mathrm{C}$; gas flow rate of $\mathrm{CH}_{4}$, $\mathrm{CO}_{2}$ and Ar: 20, 20 and $50 \mathrm{NmL} / \mathrm{min}$, respectively; $340 \mathrm{mg}$ of catalyst.

increasing the reaction temperature favors also the sintering of active metallic nanoparticles. It is needed to keep a compromise between the temperature effect on the thermodynamic and on the sintering of nanoparticles as well as the operational cost. Thus, another catalytic test was done at $750^{\circ} \mathrm{C}$ with Ni-Co/HAP_SIWI. Despite not showing the better catalytic performance among the three catalysts investigated at $700{ }^{\circ} \mathrm{C}$, Ni-Co/HAP_SIWI catalyst suffered of sintering of metals particles in a very low extent, which resulted in very low solid carbon selectivity. Thus, this catalyst was chosen for the investigation of the influence of temperature. The results are presented in Fig. 12. As expected, increasing the reaction temperature from 700 to $750{ }^{\circ} \mathrm{C}$ allowed 
Table 4

Examples of the catalytic performance of Ni- and Co-based catalysts at $700-750{ }^{\circ} \mathrm{C}$ in DRM.

\begin{tabular}{|c|c|c|c|c|c|c|c|c|c|}
\hline $\begin{array}{l}\text { Metal and its content } \\
\text { (wt.\%) }\end{array}$ & Support & $\begin{array}{l}\text { Catalyst weight, } \\
\text { mg }\end{array}$ & $\begin{array}{l}\text { Inlet gas composition, } \\
\text { vol. } \%\end{array}$ & Gas feeding & $\begin{array}{l}\mathrm{T}\left({ }^{\circ} \mathrm{C}\right) / \mathrm{P} \\
\text { (bar) }\end{array}$ & $\begin{array}{l}\mathrm{CH}_{4} \text { conv., } \\
\%\end{array}$ & $\begin{array}{l}\mathrm{CO}_{2} \text { conv., } \\
\%\end{array}$ & $\begin{array}{l}\text { Time-on- } \\
\text { stream, h }\end{array}$ & Ref. \\
\hline $5.1 \% \mathrm{Ni}$ & $\mathrm{Ce}_{0.15} \mathrm{Zr}_{0.85} \mathrm{O}_{2}$ & 50 & $50 \% \mathrm{CO}_{2}, 50 \% \mathrm{CH}_{4}$ & $60,000^{\mathrm{a}}$ & $750 / 1$ & $\approx 85$ & $\approx 85$ & 70 & {$[61]$} \\
\hline $5.9 \% \mathrm{Ni}$ & $\mathrm{Y}_{2} \mathrm{O}_{3}-\mathrm{ZrO}_{2}$ & 50 & $4 \% \mathrm{CO}_{2}, 4 \% \mathrm{CH}_{4}, 92 \% \mathrm{He}$ & $120,000^{\mathrm{a}}$ & $750 / 1$ & $\approx 93$ & $\approx 90$ & 25 & {$[61]$} \\
\hline $14.6 \% \mathrm{Ni}$ & $\mathrm{Al}_{2} \mathrm{O}_{3}$ & 50 & $4 \% \mathrm{CO}_{2}, 4 \% \mathrm{CH}_{4}, 92 \% \mathrm{He}$ & $120,000^{\mathrm{a}}$ & $750 / 1$ & $\approx 10$ & $\approx 20$ & 5 & {$[61]$} \\
\hline $10 \% \mathrm{Ni}$ & $\mathrm{Al}_{2} \mathrm{O}_{3}$ & 100 & $\begin{array}{l}40 \% \mathrm{CO}_{2}, 40 \% \mathrm{CH}_{4}, 20 \% \\
\mathrm{~N}_{2}\end{array}$ & $100^{\mathrm{b}}$ & $750 / 1$ & 48 & 48 & 100 & [62] \\
\hline $10 \% \mathrm{Ni}$ & $\begin{array}{l}\text { Phosphate-modified } \\
\mathrm{Al}_{2} \mathrm{O}_{3}\end{array}$ & 100 & $\begin{array}{l}40 \% \mathrm{CO}_{2}, 40 \% \mathrm{CH}_{4}, 20 \% \\
\mathrm{~N}_{2}\end{array}$ & $100^{\mathrm{b}}$ & $750 / 1$ & 58 & 57 & 100 & {$[62]$} \\
\hline $10 \% \mathrm{Ni}-3 \% \mathrm{Co}$ & $\mathrm{Al}_{2} \mathrm{O}_{3}-\mathrm{ZrO}_{2}$ & 100 & $50 \% \mathrm{CO}_{2}, 50 \% \mathrm{CH}_{4}$ & $40^{\mathrm{b}}$ & $750 / 1$ & $\approx 80$ & $\approx 90$ & n.r. & {$[63]$} \\
\hline $2 \% \mathrm{Ni}-1 \% \mathrm{Co}$ & $\mathrm{CeZrO}_{2} / \beta-\mathrm{SiC}$ & 500 & $50 \% \mathrm{CO}_{2}, 50 \% \mathrm{CH}_{4}$ & $100^{\mathrm{b}}$ & $750 / 1.2$ & $\approx 65$ & $\approx 75$ & $100-550$ & [64] \\
\hline $2.8 \% \mathrm{Ni}-2.8 \% \mathrm{Co}$ & HAP & 340 & $\begin{array}{l}20 \% \mathrm{CO}_{2}, 20 \% \mathrm{CH}_{4}, 60 \% \\
\mathrm{~N}_{2}\end{array}$ & $90^{\mathrm{b}}$ & $750 / 1.6$ & 73 & 79 & 160 & $\begin{array}{l}\text { This } \\
\text { work }\end{array}$ \\
\hline $10 \% \mathrm{Ni}$ & $\mathrm{SiO}_{2}$ & 200 & $50 \% \mathrm{CO}_{2}, 50 \% \mathrm{CH}_{4}$ & $40^{\mathrm{b}}$ & $700 / 1$ & $\approx 50$ & $\approx 62$ & 5 & {$[65]$} \\
\hline $10 \%$ Co & $\mathrm{SiO}_{2}$ & 200 & $50 \% \mathrm{CO}_{2}, 50 \% \mathrm{CH}_{4}$ & $40^{\mathrm{b}}$ & $700 / 1$ & $\approx 21$ & $\approx 35$ & 5 & {$[65]$} \\
\hline $2.8 \% \mathrm{Ni}-2.8 \% \mathrm{Co}$ & HAP & 340 & $\begin{array}{l}20 \% \mathrm{CO}_{2}, 20 \% \mathrm{CH}_{4}, 60 \% \\
\mathrm{~N}_{2}\end{array}$ & $90^{\mathrm{b}}$ & $700 / 1.6$ & 60 & 68 & 160 & $\begin{array}{l}\text { This } \\
\text { work }\end{array}$ \\
\hline
\end{tabular}

a Space velocity, $\mathrm{cm}^{3} \mathrm{~h}^{-1} \mathrm{~g}^{-1}$.

${ }^{\mathrm{b}} \mathrm{Ncm}^{3} / \mathrm{min}$; n.r.: not reported.

increasing the conversion of both $\mathrm{CH}_{4}$ and $\mathrm{CO}_{2}$ from around 60 and 68\% (Fig. 7) to around 73 and 79\% (Fig. 12A), respectively. An initial catalytic deactivation was also observed at the beginning of the reaction. Then the catalytic activity was kept stable for a long reaction time of $160 \mathrm{~h}$.

Water was also formed as a by-product of the reaction and its selectivity was stable around $12 \%$. This was slightly lower than the values observed at $700{ }^{\circ} \mathrm{C}$ (Fig. 8). Thermodynamic prediction shows that both water and carbon deposition decrease with the increase of the reaction temperature $[13,49]$. This could be resulted from the reaction between coke and water vapor (Eq. (14)).

$$
\mathrm{C}+\mathrm{H}_{2} \mathrm{O} \rightarrow 2 \mathrm{CO}
$$

Fig. 12C shows the selectivity into $\mathrm{H}_{2}$ and $\mathrm{CO}$. The results were similar to those obtained at $700{ }^{\circ} \mathrm{C}$. After an initial deactivation during the first $20 \mathrm{~h}$ of reaction, the selectivity into both $\mathrm{H}_{2}$ and $\mathrm{CO}$ was stable around 75 and $85 \%$, respectively. The $\mathrm{H}_{2}$ selectivity was lower than the CO selectivity which was explained by RWGS reaction. Also, $\mathrm{C}_{(\mathrm{s})}$ selectivity was very low $(\approx 10 \%)$ during the $160 \mathrm{~h}$ of TOS (result not shown here). Finally, the $\mathrm{H}_{2}$ to $\mathrm{CO}$ molar ratio was close to $90 \%$, as already observed at $700{ }^{\circ} \mathrm{C}$.

As conclusion, the increase of the reaction temperature from 700 to $750{ }^{\circ} \mathrm{C}$ allowed significantly increasing the conversion of both $\mathrm{CH}_{4}$ and $\mathrm{CO}_{2}$ with the similar catalytic selectivity and stability of $\mathrm{Ni}-\mathrm{Co} /$ HAP_SIWI catalyst.

Table 4 compares the performance of hydroxyapatite-based catalysts to those of catalysts prepared with conventional supports for DRM reaction under similar experimental conditions. For both the temperature of 700 and $750{ }^{\circ} \mathrm{C}$, hydroxyapatite supported bimetallic Ni-Co catalysts prepared in this work were found to be competitive versus other nickel and cobalt catalysts supported on the conventional supports like alumina, silica, zirconium oxide, ceria, and SiC. So, hydroxyapatite-based catalysts merit to be further studied for DRM reaction as well as for other reforming and heterogeneous catalytic processes.

\section{Conclusions}

For the first time, hydroxyapatite supported bimetallic Ni-Co catalysts were prepared, characterized and studied in DRM reaction. In all cases, bimetallic nanoparticles containing both $\mathrm{Ni}$ and Co were formed, regardless of the preparation methods. Ni-Co particles of dozens $\mathrm{nm}$ could be clearly observed on the surface of HAP support by TEM-EDX analysis. No modification of HAP support structure was observed after $\mathrm{Ni}$-Co deposition, except the superficial cationic exchange of $\mathrm{Ca}^{2+}$ with
$\mathrm{Ni}^{2+}$ and $\mathrm{Co}^{2+}$.

DRM reaction was carried out at 700 and $750{ }^{\circ} \mathrm{C}$ and 1.6 bar with an equimolar mixture of $\mathrm{CO}_{2}$ and $\mathrm{CH}_{4}$ diluted in $\mathrm{N}_{2}$ (60\%vol.). All the prepared catalysts showed high catalytic activity and stability. For each catalytic test, an initial catalytic deactivation took place within the first $10 \mathrm{~h}$ of time-on-stream (TOS). Then the catalytic activity was stable up to 50 or $160 \mathrm{~h}$ of TOS. $\mathrm{CO}$ and $\mathrm{H}_{2}$ were the main products of the reaction and their selectivity reached about $80-90 \%$. Reverse WGS also occurred, which led to the formation of water as by-product, to the higher conversion of $\mathrm{CO}_{2}$ compared to that of $\mathrm{CH}_{4}$, and to the $\mathrm{H}_{2} / \mathrm{CO}$ molar ratio close to $90 \%$.

All the prepared catalysts showed good catalytic stability during DRM reaction. This was explained by the formation of carbonaceous species under CNTs form at low content. Other kinds of carbon such as amorphous carbon or core-shell carbon, which mainly causes the catalytic deactivation in DRM reaction, were not observed.

\section{Acknowledgments}

The authors gratefully thank ADEME (Agence de l'environnement et de la maîtrise de l'énergie, France, for the financial support of the VABHYOGAZ3 project) and PRAYON for their supports. The authors also thank our colleagues at the RAPSODEE center (CNRS UMR 5302) for technical help.

\section{Appendix A. Supplementary data}

Supplementary data associated with this article can be found, in the online version, at http://dx.doi.org/10.1016/j.apcatb.2017.10.063.

\section{References}

[1] R.C. Brown, Thermochemical Processing of Biomass Conversion into Fuels, Chemicals and Power. Chapter I-Introduction to Thermochemical Processing of Biomass into Fuels, Chemicals, and Power, John Wiley \& Sons, Ltd., 2011.

[2] F.X. Collard, J.A. Blin, A review on pyrolysis of biomass constituents: mechanisms and composition of the products obtained from the conversion of cellulose, hemicelluloses and lignin, Renew. Sustain. Energy Rev. 38 (2014) 594-608.

[3] V.S. Sikarwar, M. Zhao, P.S. Fennell, N. Shah, E.J. Anthony, Progress in biofuel production from gasification, Prog. Energy Combust. Sci. 61 (2017) 189-248.

[4] S.R.A. Kersten, X. Wang, W. Prins, W.P.M. van Swaaij, Biomass pyrolysis in a fluidized bed reactor. Part 1: literature review and model simulations, Ind. Eng. Chem. Res. 44 (2005) 8773-8785.

[5] B. Lai Fui Chin, A. Gorin, H.B. Chua, Biomass Derived Syngas Cleaning Technologies, LAP LAMBERT Academic publishing, 2014, 2017.

[6] D. De Clercq, Z. Wen, O. Gottfried, F. Schmidt, F. Fei, A review of global strategies promoting the conversion of food waste to bioenergy via anaerobic digestion, Renew. Sustain. Energy Rev. 79 (2017) 204-221.

[7] K. Hagos, J. Zong, D. Li, C. Liu, X. Lu, Anaerobic co-digestion process for biogas 
production: progress, challenges and perspectives, Renew. Sustain. Energy Rev. 76 (2017) 1485-1496.

[8] A. Löfberg, T. Kane, J. Guerrero-Caballero, L. Jalowiecki-Duhamel, Chemical looping dry reforming of methane: toward shale-gas and biogas valorization, Chem. Eng. Proc: Proc. Intens. https://doi.org/10.1016/j.cep.2017.05.003. (Available online 10 May 2017).

[9] M. Jafarbegloo, A. Tarlani, A.W. Mesbah, S. Sahebdelfar, Thermodynamic analysis of carbon dioxide reforming of methane and its practical relevance, Int. J. Hydrogen Energy 40 (2015) 2445-2451.

[10] R.Y. Chein, Y.C. Chen, C.T. Yu, J.N. Chung, Thermodynamic analysis of dry reforming of $\mathrm{CH}_{4}$ with $\mathrm{CO}_{2}$ at high pressures, J. Nat. Gas Sci. Eng. 26 (2015) 617-629.

[11] B. Rêgo De Vasconcelos, L. Zhao, P. Sharrock, A. Nzihou, D. Pham Minh, Catalytic transformation of carbon dioxide and methane into syngas over ruthenium and platinum supported hydroxyapatites, Appl. Surf. Sci. 390 (2016) 141-156.

[12] S. de Llobet, J.L. Pinilla, R. Moliner, I. Suelves, Relationship between carbon morphology and catalyst deactivation in the catalytic decomposition of biogas using $\mathrm{Ni}, \mathrm{Co}$ and Fe based catalysts, Fuel 139 (2015) 71-78.

[13] B. Rêgo De Vasconcelos, Phosphates-based Catalysts for Synthetic Gas (syngas) Production Using $\mathrm{CO}_{2}$ and $\mathrm{CH}_{4}$. PhD Report, Ecole Nationale Supérieure des Mines d'Albi-Carmaux, France, 2015.

[14] M. Luneau, E. Gianotti, F.C. Meunier, C. Mirodatos, E. Puzenat, Y. Schuurman, N. Guilhaume, Deactivation mechanism of Ni supported on Mg-Al spinel during autothermal reforming of model biogas, Appl. Catal. B: Environ. 203 (2017) 289-299.

[15] J.M. Ginsburg, J. Piña, T. El Solh, H.I. de Lasa, Coke formation over a nickel catalyst under methane dry reforming conditions: thermodynamic and kinetic models, Ind. Eng. Chem. Res. 44 (2005) 4846-4854.

[16] J.H. Kim, D.J. Suh, T.J. Park, K.L. Kim, Effect of metal particle size on coking during $\mathrm{CO}_{2}$ reforming of $\mathrm{CH}_{4}$ over Ni-alumina aerogel catalysts, Appl. Catal. A Gen. 197 (2000) 191-200.

[17] C.J. Liu, J. Ye, J. Jiang, Y. Pan, Progresses in the preparation of coke resistant Nibased catalyst for steam and $\mathrm{CO}_{2}$ reforming of methane, ChemCatChem 3 (2011) 529-541.

[18] L. Mo, E.T. Saw, Y. Du, A. Borgna, M.L. Ang, Y. Kathiraser, Z. Li, W. Thitsartarn, M. Lin, S. Kawi, Highly dispersed supported metal catalysts prepared via in-situ selfassembled core-shell precursor route, Int. J. Hydrogen Energy 40 (2015) $13388-13398$.

[19] A. Alipour, M. Rezaei, F. Meshkani, Effect of alkaline earth promoters ( $\mathrm{MgO} \mathrm{CaO}$, and $\mathrm{BaO}$ ) on the activity and coke formation of $\mathrm{Ni}$ catalysts supported on nanocrystalline $\mathrm{Al}_{2} \mathrm{O}_{3}$ in dry reforming of methane, J. Ind. Eng. Chem. 20 (2014) crystalline

[20] D. San José-Alonso, M.J. Illán-Gómez, M.C. Román-Martínez, K and Sr promoted Co alumina supported catalysts for the $\mathrm{CO}_{2}$ reforming of methane, Catal. Today 176 (2011) 187-190.

[21] M.A. Goula, N.D. Charisiou, G. Siakavelas, L. Tzounis, I. Tsiaoussis, P. Panagiotopoulou, G. Goula, I.V. Yentekakis, Syngas production via the biogas dry reforming reaction over $\mathrm{Ni}$ supported on zirconia modified with $\mathrm{CeO}_{2}$ or $\mathrm{La}_{2} \mathrm{O}_{3}$ catalysts, Int. J. Hydrogen Energy 42 (2017) 13724-13740.

[22] E. Dahdah, J. Abou Rached, S. Aouad, C. Gennequin, H.L. Tidahy, J. Estephane, A. Aboukaïs, E. Abi Aad, $\mathrm{CO}_{2}$ reforming of methane over $\mathrm{Ni}_{\mathrm{x}} \mathrm{Mg}_{6-\mathrm{x}} \mathrm{Al}_{2}$ catalysts: effect of lanthanum doping on catalytic activity and stability, Int. J. Hydrogen Energy 42 (2017) 12808-12817.

[23] H. Liu, D. Wierzbicki, R. Debek, M. Motak, T. Grzybek, P. Da Costa, M. Elena Gálvez, La-promoted Ni-hydrotalcite-derived catalysts for dry reforming of methane at low temperatures, Fuel 182 (2016) 8-16.

[24] A. Löfberg, J. Guerrero-Caballero, T. Kane, A. Rubbens, L. Jalowiecki-Duhamel, Ni/ $\mathrm{CeO}_{2}$ based catalysts as oxygen vectors for the chemical looping dry reforming of methane for syngas production, Appl. Catal. B: Environ. 212 (2017) 159-174.

[25] B. Abdullah, N. Azeanni Abd Ghani, D.V.N. Vo, Recent advances in dry reforming of methane over Ni-based catalysts, J. Clean. Prod. 162 (2017) 170-185.

[26] Z. Taherian, M. Yousefpour, M. Tajally, B. Khoshandam, Promotional effect of samarium on the activity and stability of Ni-SBA-15 catalysts in dry reforming of methane, Micropour. Mesopour. Mat. 251 (2017) 9-18.

[27] G. Nahara, D. Mote, V. Dupont, Hydrogen production from reforming of biogas: review of technological advances and an Indian perspective, Renew. Sustain. Energy Rev. 76 (2017) 1032-1052.

[28] G.G. Meric, H. Arbag, L. Degirmenci, Coke minimization via SiC formation in dry reforming of methane conducted in the presence of Ni-based core-shell microsphere catalysts, Int. J. Hydrogen Energy 42 (2017) 16579-16588.

[29] Z. Taherian, M. Yousefpour, M. Tajally, B. Khoshandam, A comparative study of $\mathrm{ZrO}_{2}, \mathrm{Y}_{2} \mathrm{O}_{3}$ and $\mathrm{Sm}_{2} \mathrm{O}_{3}$ promoted Ni/SBA-15 catalysts for evaluation of $\mathrm{CO}_{2} / \mathrm{me}-$ thane reforming performance, Int. J. Hydrogen Energy 42 (2017) 16408-16420.

[30] A. Movasati, S.M. Alavi, G. Mazloom, $\mathrm{CO}_{2}$ reforming of methane over $\mathrm{Ni} / \mathrm{ZnAl}_{2} \mathrm{O}_{4}$ catalysts: influence of Ce addition on activity and stability, Int. J. Hydrogen Energy 42 (2017) 16436-16448.

[31] M. Galera Martínez, D. Pham Minh, E. Weiss-Hortala, A. Nzihou, P. Sharrock, Synthesis, characterization and thermo-mechanical properties of copper loaded apatitic calcium phosphates, Comput. Interface 20 (2013) 647-660.

[32] B. Rêgo De Vasconcelos, D. Pham Minh, N.D. Tran, A. Nzihou, P. Sharrock, Synthesis of carbon nanotubes/hydroxyapatite composites using catalytic methane cracking, Comput. Interface 22 (2015) 673-687.

[33] D. Pham Minh, N.D. Tran, A. Nzihou, P. Sharrock, One-step synthesis of calcium hydroxyapatite from calcium carbonate and orthophosphoric acid under moderate conditions, Ind. Eng. Chem. Res. 52 (2013) 1439-1447.

[34] A. Ababou, D. Bernarche-Assolant, M. Heughebaert, Influence des conditions de calcination sur l'évolution morphologique de l'hydroxyapatite, Ann. Chim. 19 (1994) 165-175.

[35] D. Bernache-assollant, A. Ababou, E. Champion, M. Heughebaert, Sintering of calcium phosphate hydroxyapatite $\mathrm{Ca}_{10}\left(\mathrm{PO}_{4}\right)_{6}(\mathrm{OH})_{2}$ I. Calcination and particle growth, J. Eur. Ceram. Soc. 23 (2003) 229-241.

[36] Z. Boukha, M. Kacimi, M.F. Pereira, J.L. Faria, J.L. Figueiredo, M. Ziyad, Methane dry reforming on Ni loaded hydroxyapatite and fluoroapatite, Appl. Catal. A: Gen. 317 (2007) 299-309.

[37] K. Takanabe, K. Nagaoka, K. Nariai, K. Aika, Titania-supported bimetallic catalysts for carbon dioxide reforming of methane, J. Catal. 232 (2005) 268-275.

[38] J. Zhang, H. Wang, A.K. Dalai, Development of stable bimetallic catalysts for carbon dioxide reforming of methane, J. Catal. 249 (2007) 300-301.

[39] C. Wang, N. Sun, N. Zhao, W. Wei, Y. Zhao, Template-free preparation of bimetallic mesoporous $\mathrm{Ni}-\mathrm{Co}-\mathrm{CaO}-\mathrm{ZrO}_{2}$ catalysts and their synergetic effect in dry reforming of methane, Catal. Today 281 (2017) 268-275.

[40] M. Miyake, K. Watanabe, Y. Nagayama, H. Nagasawa, T. Suzuki, Synthetic carbonate apatites as inorganic cation exchangers, J. Chem. Soc. Faraday Trans. 86 (1990) 2303-2306.

[41] D. Pham Minh, H. Sebei, A. Nzihou, P. Sharrock, Apatitic calcium phosphates: synthesis, characterization and reactivity in the removal of lead(II) from aqueous solution, Chem. Eng. J. 198-199 (2012) 180-190.

[42] B. Rego de Vasconcelos, D. Pham Minh, P. Sharrock, A. Nzihou, Regeneration study of $\mathrm{Ni} /$ hydroxyapatite spent catalyst from dry reforming, Catal. Today, http://dx doi.org/10.1016/j.cattod.2017.05.092. (Available online 9 June 2017).

[43] J. Xu, W. Zhou, Z. Li, J. Wang, J. Ma, Biogas reforming for hydrogen production over nickel and cobalt bimetallic catalysts, Int. J. Hydrogen Energy 34 (2009) 6646-6654.

[44] M.S. Aw, I.G.O. Crnivec, P. Djinovic, A. Pintar, Strategies to enhance dry reforming of methane: synthesis of ceria-zirconia/nickelecobalt catalysts by freeze-drying and NO calcination, Int. J. Hydrogen Energy 39 (2014) 12636-12647.

[45] J.D.A. Bellido, J.E. De Souza, J.C. M’Peko, E.M. Assaf, Effect of adding $\mathrm{CaO}$ to $\mathrm{ZrO}_{2}$ support on nickel catalyst activity in dry reforming of methane, Appl. Catal. A: Gen. 358 (2009) 215-223.

[46] R. Amin, B. Liu, S. Ullah, H.Z. Biao, Study of coking and catalyst stability over $\mathrm{CaO}$ promoted Ni-based MCF synthesized by different methods for $\mathrm{CH}_{4} / \mathrm{CO}_{2}$ reforming reaction, Int. J. Hydrogen Energy 42 (2017) 21607-21616.

[47] B. Bachiller-Baeza, C. Mateos-Pedrero, M.A. Soria, A. Guerrero-Ruiz, U. Rodemerck, I. Rodríguez-Ramos, Transient studies of low-temperature dry reforming of methane over Ni-CaO/ $/ \mathrm{ZrO}_{2}-\mathrm{La}_{2} \mathrm{O}_{3}$, Appl. Catal. B: Environ. 129 (2013) 450-459.

[48] A. Serrano-Lotina, L. Daza, Influence of the operating parameters over dry reforming of methane to syngas, Int. J. Hydrogen Energy 39 (2014) 4089-4094.

[49] M.A. Soria, C. Mateos-Pedrero, A. Guerrero-Ruiz, I. Rodriguez-Ramos, Thermodynamic and experimental study of combined dry and steam reforming of methane on $\mathrm{Ru} / \mathrm{ZrO}_{2}-\mathrm{La}_{2} \mathrm{O}_{3}$ catalyst at low temperature, Int. J. Hydrogen Energy 36 (2011) 15212-15220.

[50] R.V. Goncalvesa, L.L.R. Vono, R. Wojcieszak, C.S.B. Dias, H. Wender, E. TeixeiraNeto, L.M. Rossi, Selective hydrogenation of $\mathrm{CO}_{2}$ into $\mathrm{CO}$ on a highly dispersed nickel catalyst obtained by magnetron sputtering deposition: a step towards liquid fuels, Appl. Catal. B: Environ. 209 (2017) 240-246.

[51] L. Wang, H. Liu, Y. Chen, S. Yang, Reverse water-gas shift reaction over co-precipitated $\mathrm{Co}-\mathrm{CeO}_{2}$ catalysts: effect of Co content on selectivity and carbon formation, Int. J. Hydrogen Energy 42 (2017) 3682-3689.

[52] J. Huo, J. Jing, W. Li, Reduction time effect on structure and performance of Ni-Co/ $\mathrm{MgO}$ catalyst for carbon dioxide reforming of methane, Int. J. Hydrogen Energy 39 (2014) 21015-21023.

[53] M. Fan, A.A. Adbullah, S. Bhatia, Catalytic technology for carbon dioxide reforming of methane to synthesis gas, ChemCatChem 1 (2009) 192-208.

[54] F.R. Shamskar, M. Rezaei, F. Meshkani, The influence of Ni loading on the activity and coke formation of ultrasound-assisted co-precipitated $\mathrm{Ni} / \mathrm{Al}_{2} \mathrm{O}_{3}$ nanocatalyst in dry reforming of methane, Int. J. Hydrogen Energy 42 (2017) 4155-4164.

[55] C. Wang, N. Sun, N. Zhao, W. Wei, Y. Sun, C. Sun, H. Liu, C.E. Snape, Coking and deactivation of a mesoporous $\mathrm{Ni}-\mathrm{CaO}-\mathrm{ZrO}_{2}$ catalyst in dry reforming of methane: a study under different feeding compositions, Fuel 143 (2015) 527-535.

[56] A. Wolfbeisser, O. Sophiphun, J. Bernardi, J. Wittayakun, K. Föttinger, G. Rupprechter, Methane dry reforming over ceria-zirconia supported Ni catalysts, Catal. Today 277 (2016) 234-245.

[57] J. Kim, D.J. Suh, T. Park, K. Kim, Effect of metal particle on coking during $\mathrm{CO}_{2}$ reforming of $\mathrm{CH}_{4}$ over Ni-alumina aerogel catalysts, Appl. Catal. A: Gen. 197 (2000) $191-200$.

[58] M. Usman, W.M.A.W. Daud, Hazzim F. Abbas, Dry reforming of methane: influence of process parameters - a review, Renew. Suistain. Energy Rev. 45 (2015) 710-744.

[59] H. Ay, D. Uner, Dry reforming of methane over $\mathrm{CeO}_{2}$ supported $\mathrm{Ni} \mathrm{Co}$, and Ni-Co catalysts, Appl. Catal. B: Environ. 179 (2015) 128-138.

[60] M.S. Challiwala, M.M. Ghouri, P. Linke, M.M. El-Halwagi, N.O. Elbashir, A combined thermo-kinetic analysis of various methane reforming technologies: comparison with dry reforming, J. $\mathrm{CO}_{2}$ Utiliz. 17 (2017) 99-111.

[61] M.A. Munoz, J.J. Calvino, J.M. Rodríguez-Izquierdo, G. Blanco, D.C. Arias, J.A. Pérez-Omil, J.C. Hernández-Garrido, J.M. González-Leal, M.A. Cauqui, M.P. Yeste, Highly stable ceria-zirconia-yttria supported Ni catalysts for syngas production by $\mathrm{CO}_{2}$ reforming of methane, Appl. Surf. Sci. 426 (2017) 864-873.

[62] S. Bang, E. Hong, S.W. Baek, C.H. Shin, Effect of acidity on Ni catalysts supported on P-modified $\mathrm{Al} 2 \mathrm{O} 3$ for dry reforming of methane, Catal. Today, http://dx.doi.org/ 10.1016/j.cattod.2017.08.013. (Available online 10 August 2017).

[63] S. Mahboob, M. Haghighi, F. Rahmani, Sonochemically preparation and characterization of bimetallic Ni-Co/ $\mathrm{Al}_{2} \mathrm{O}_{3}-\mathrm{ZrO}_{2}$ nanocatalyst: effects of ultrasound irradiation time and power on catalytic properties and activity in dry reforming of $\mathrm{CH}_{4}$, Ultrasonics Sonochem. 38 (2017) 38-49.

[64] P. Djinovic, A. Pintar, Stable and selective syngas production from dry $\mathrm{CH}_{4}-\mathrm{CO}_{2}$ stream sover supported bimetallic transition metal catalysts, Appl. Catal. B: Environ. 206 (2017) 675-682.

[65] Z. Taherian, M. Yousefpour, M. Tajally, B. Khoshandam, Catalytic performance of samaria-promoted Ni and Co/SBA-15 catalysts for dry reforming of methane, Int. J. Hydrogen Energy 42 (2017) 24811-24822. 